\title{
A Cognitive Approach to Interdiscursivity: A Case of a Literary Discourse
}

\author{
Badriah Khalid Al-Gublan \\ Associate Professor, Applied Linguistics \\ English Langauge and Literature Department, College of Arts, Princess Nora Bint \\ Abdulrahman University, Riyadh, Saudi Arabia \\ Tel: 966-555-196-667Ｅ-mail: Bkh-g@hotmail.com
}

Received: March 7, 2015 Accepted: April 10, 2015 Published: April 11, 2015

doi:10.5296/elr.v1i1.7422 URL: http://dx.doi.org/10.5296/elr.v1i1.7422

\begin{abstract}
The research aims at investigating the mechanisms which lie behind interdiscursivity, the force that prompts language users to choose it in communication and the effects it can achieve on the basis of Sperber \& Wilson's Relevance Theory.

This is an attempt to show the situational, social, and mental dimensions of the role of nterdiscursivity using a number of Relevance Theory concepts, including ostensive behaviour, cognitive environments and implicatures treating interdiscursivity as an ostensive or marked form of communication.
\end{abstract}

Keywords: Interdiscursivity, Relevance theory, Ostensive behavior, Implicature, Cognitive environments 


\section{Introduction}

Interdiscursivity refers to the mixing of diverse genres, discourses, or styles associated with institutional and social meanings in a single text. The major concerns of this approach are how literary texts are formed through interdiscursivity and what aesthetic as well as social significance are achieved through this text-forming scheme. This is a very important notion in that it allows us to understand more specifically the textuality of hegemony, or in other words, the discursive processes by means of which subjects are produced and the common sense maintained.

\section{Review of the Related Literature}

The concept of interdiscursivity can be traced back to Bhakti's dialogized "heteroglossia" (Bakhtin, 1981, 1986). For Bakhtin, utterances in language are always dialogized and changing which results in what he calls "hybridization"- the mixture of different utterances within a single piece of language. Bakhtin describes this complex mixture of utterances as heteroglossia. What Bakhtin holds in terms of the concept of dialogized heteroglossia indicates the issue of interdiscursivity. He is more concerned with the language in specific social situations. Kristeva (1986) introduces Bakhtin's theory into France and coined the phrase "Constitutive intertextuality". For him (1986), 'Constitutive intertextuality' implies "the insertion of history (society) into a text and of this text into history" (p. 39). Fairclough (1992) defines 'Constitutive intertextuality' basically as the mixing configuration of discourse conventions such as genres, activity types, and styles associated with different types of discourse (p. 84). As a special kind of intertextuality, interdiscursivity is related to the whole language system involved in a text. In order to emphasize that the focus is on discourse conventions rather than other texts as constitutive, Fairclough (1992, 2003, 2010) uses the new term 'interdiscursivity' to replace "constitutive intertextuality". He (2010) thinks that 'interdiscursivity' is more than a stylistic phenomenon; rather, it has important implications for social practice. Thus, 'interdiscursivity' is central to an understanding of the process of social change. As Allen (2000) suggests that 'interdiscursivity' is a term by no means exclusively related to the study of literary works or to written communication in general.

The major concerns of the stylistic approach are how literary texts are formed through interdiscursivity and what aesthetic as well as social significances are achieved through this text-forming scheme. Bakhtin $(1981,1986)$ explores the reasons for genre mixing by examining the artistic and ideological resonances of literary and non-literary styles in a text. For him, poetry is formal and stylistic difference from the context-influenced style of non-poetic language indicates a thinking and behavioral pattern that is free from the dangerous contamination of ordinary life. He further emphasizes that novel is a pluralistic discourse. It intentionally mixes many different genres which are widely separated in time and social space. This conscious genre hybridization is a major device for creating artistic language-images in the novel (Bakhtin, 1981, pp. 358-366). However, to Bakhtin, this genre hybridization is not an easy process; it implies friction and struggle. Toward the end of the 20th century, there have appeared quite a few broad studies on interdiscursivity in photographs and films. For example, Collins (1989) and Hutcheon (1989) have explored the political dimensions of postmodern texts by focusing specifically on the ideological 


\section{Al Macrothink}

significance of genre combination in films. Knee (1994), however, takes genre compounding or hybridizing in films as a means of weaving together the plots. But the most detailed exploration of interdiscursivity is found in Bradford (1997), where he applies his theory of 'double pattern' to the analysis of genre mixing and/or genre switching in poetry, novel, and drama. For him, the interdiscursive feature of poetry is the main factor that gives rise to the tension between the two poles of the "double pattern". He (1997) ascribes this kind of interdiscursivity to the political and social disorders at that time. This mode of interdiscursivity, however, is more clearly shown in Shakespeare's dramas. He (1997) even thinks that this genre mixing in Shakespeare's dramas maps the distinction between the European civilization and the savages of the new world. For him (1997), the novel is an all-inclusive framework of genres and linguistic styles.

\section{The Objective of the Study}

The research aims at studying the mechanisms which lie behind interdiscursivity, the force that prompts language users to choose it in communication and the effects it can achieve on the basis of Sperber \& Wilson's Relevance Theory.

\section{The Statement of the Problem}

The existing researches still have a lot of limitations, and more efforts are needed to further explore the complexities of interdiscursivity. In the first place, neither of the above-mentioned approaches is comprehensive enough since they never touch upon the cognitive factors lying behind the functioning of interdiscursivity. This undesirable situation shows that in interdiscursivity studies what actually lacks is an applicable theoretical framework which is based upon the cognitive, social, and cultural dimensions of language use. Consequently, the future study should attempt to generate an encompassing theoretical framework, and investigate interdiscursivity in more details. Such analyses from the stylistic approach focus on the surface level and fail to reveal in depth the operating process of interdiscursivity, for they do not take the dynamics of communication and the cognitive elements into consideration. Furthermore, no satisfactory theoretical model for the understanding of interdiscursivity has been offered in the stylistic approach.

\section{The Significance of the Study}

The functioning of interdiscursivity as a special kind of linguistic phenomenon is closely related to the cognitive, social, and cultural factors of language use. An interdiscursive text, with its elements rooted in particular institutions, is not individual and idiosyncratic; but part of a shared cultural world. However, as mentioned above, the previous studies of interdiscursivity are rather incomplete, the have left the cognitive facet intact and they have never fully unveiled the specific motivations lying behind the choices of interdiscursivity. In view of this limitation, the pragmatic perspective is conducted in this study in order to reveal the underlying force that drives language users to choose interdiscursivity and provide a systematic and coherent analysis for this linguistic phenomenon in a literary discourse.

\section{The Model of the Study}

Relevance Theory (hereafter RT) is a means of describing interactions by adopting the asocial notion of relevance as the driving force incommunication. In doing so, RT acts as a potentially neutral starting point for discussion social verbal behaviour. Relevance and its 
notion of ostensive behaviour will be used to posit markedness, a marked ostensive form.

\subsection{Relevance Theory}

RT is a theory of communication which was originally proposed by Sperber and Wilson (1986-1995) (hereafter S\&W). According to S\&W, communication occurs within the interactants mutual cognitive environment. In RT, cognitive environments are considered the most accessible context, and are taken to mean the psychological constructs containing actors assumptions about the world in (S\&W, 1986, 15). However, S\&W (1982) do not equate mutual cognitive environments with the more traditional concept of the mutual knowledge. They reiterate the dilemma of how to compute an infinite set of propositions (S knows that $\mathrm{P}$, A knows that $\mathrm{P}, \mathrm{S}$ knows that $\mathrm{A}$ knows that $\mathrm{P}$ an infinitum) in a finite length of time (p. 63). Mutual cognitive environments are posited as a solution to this problem with an individual choosing from contexts, pertinent to the interaction, and bringing these to the communicative space (S\&W, 1986, 39). The mutual cognitive environment is then the most immediately accessible context at the time of the utterance. It is not pre-existing or given, but chosen and shaped as an interaction begins (S\&W, 1982, 7); (Pilkington, 1991, 54). This environment is." (Nicolle, 1999, 677), "guide” (Yus Ramos, 1998, 317), or methods of "special help" (Wilson then developed more fully throughout the interaction. The initial context is constructed from the immediately preceding utterances (S\&W, 1982,76$)$, and is then expanded by information from, not only previous utterances, but also the interactants' encyclopaedic memory and the present physical environment (S\&W, 1982, 703). Thus context, in S\&W's terms, is quite dynamic and changing rather than a "monolithic entity" that every person adopts with the initiation of an interaction (Yus Ramos, 1998, 307). Interactants do not begin with a stable notion of each other, but use language to construct and reconstruct the mutual cognitive environment. According to $\mathrm{S} \& \mathrm{~W}$ 's model communication is said to occur when information becomes relevant to the mutual cognitive environment of the interactants.Information relevance is achieved through ostension, which is the act of highlighting information to create a perceptible effect on this context (S\&W, 1986, 49). Ostensive behaviour contains the presumption of relevance, a perceptible effect in an addressee's cognitive environment. Firstly, it attracts an addressee's attention, flagging the relevance of an utterance: and secondly, it makes an addressee aware that a speaker intended an addressee to notice (S\&W, 1986, 15). Ostensive behaviour uses stimulus to direct the relevance of an event. This stimulus may be nonverbal such as movement and gesture, or linguistically realized in the form of an utterance. Both are forms of marked behavior which direct an addressee to notice a piece of information by flagging its relevance. Ostensive stimuli are agents which highlight the importance of certain information for a particular situation - in RT terms the relevance of input for the addressee's cognitive environment. 


\section{Ostensive Behaviour \\ makes manifest an intention to make something manifest carries the presumption of relevance}

Ostensive Stimulus

direct the addressee to relevance

Non-Verbal Event movement and gesture noise

Verbal Eventutterance

Most of S\&W's examples of ostension come from the nonverbal rather than the linguistic branch. For instance, they describe two characters, Mary and Peter, who are sitting on apark bench. Peter leans back, changing Mary's view to reveal two people walking towards them one is unknown, but the other is William, a dreadful bore. The latter of these two people has more impact on Mary's cognitive environment because he is known to her. She thus presumes that Peter's act of leaning back is ostensive, as it intends to attract her attention, making relevant William's approach. This action makes manifest Peter's intention to make manifest William's presence (S\&W, 1986, 48). Although leaning back may be considered uninformative behaviour in some circumstances, such as merely becoming comfortable, Peter's action is regarded as ostensive due to its signpost guiding function in highlighting the importance of relevant information. S\&W (1995) provide many nonverbal examples of this sort, which are relatively unproblematic, but interestingly say little about linguistic ostension. For S\&W (1995) ostensive linguistic stimuli exist merely on the utterance level.

An ostensive stimulus makes information relevant to the interactants. This relevance is achieved through contextual effects on the interactants' mutual cognitive environment.Contextual effects must either reinforce an old assumption, derive a new one or eliminate an old assumption (S\&W, 1986, 121; Wilson and Sperber, 1986, 381), and communication cannot occur without these effects.

The combination of this linguistic and contextual information allows the retrieval of explicatures to occur through a process of disambiguation (matching linguistic forms to semantic representations), referent assignment (matching nouns to entities) and meaning enrichment (semantic representations needing more information). Explicature retrieval is then followed by are solution of the propositional attitude, the basic Speech Act mode of saying, telling or asking. Finally communication is achieved through the last step - a process of inference, involving the construction of implicatures purely from the contextual information needed to properly understand an utterance: (S\&W, 1986, 182-202). At every stage the principle of relevance is at play, as it requires that "the hearer should choose the solution [explicature/ implicature] involving the least effort, and should abandon this solution only if it fails to yield an interpretation consistent with the principle of relevance" (S\&W, 1986, 185). 


\section{Macrothink

1. Explicature Process (Linguistic decoding and contextual input)

Disambiguation

Reference Assignment

Enrichment

2. Recovering of a Propositional Attitude (Basic Speech Acts - asking, saying, telling)

3. Implicature Process (Contextual input)

Previous Utterances

Physical Environment

Encyclopaedic Memory

This process can be exemplified in the following example:

Biologist, Penelope rushes from her bedroom into the lounge room of their share housewhere her fellow biologist and flatmate Tim is sitting. She utters:

The jar is empty. Do you know where my flower is?

The first step in making sense of Penelope's utterance is to construct an explicature by retrieving semantic forms for the words. The word "flower" in the spoken form is ambiguous meaning either ground up wheat used for cooking (flour) or the seed bearing part of a plant (flower). The context of the previous utterance, "The jar is empty", does not help disambiguate this sentence, as both "flour" and a "flower" may be kept in a jar. However the fact that Penelope has come from her room and not the kitchen, which would be expected if she were looking for "flour", allows Tim to assign the latter meaning to this word. More work is needed on the phrase "my flower". The genitive in this case is not clear. "My flower" can mean a flower owned by Penelope or a new type of flower propagated by Penelope. Tim must enrich this form with contextual cues. For instance, he knows that Penelope is a biologist, so it is likely that the flower that she is referring to is one she has bred herself. If the previous utterance had been "The vase is empty", the 'owned' meaning might have been more relevant. Tim also needs to perform reference assignment with the word "you", giving it the real world referent of himself. In this process of disambiguation and enrichment the rest of these forms also receive semantic representation, such as "empty" meaning a container lacking filling. The basic Speech Act form of "asking" is then retrieved to yield the propositional form: I am asking whether you know where my flower is. However this is not the whole meaning of the utterance. It continues to direct relevance to implied meanings or the retrieval of implicatures. Implicatures may be determined by asking why an utterance: has been made. In this case Tim may recover similar scenarios from his encyclopaedic memory, regarding other instances where he has borrowed her species of flower to show to his biology class without consulting her first.

Ostension is described as the way information is communicated. It is the act of highlighting information to make it relevant, and to attract an addressee's attention to the information. Thus, ostensive behaviour may be considered as marked behaviour. However in terms of verbal ostension, S\&W (1997) consider the utterance to be the only verbal entity which carries relevance. Wilson (1998) suggests that "every ostensive stimulus creates a presumption of optimal relevance, and it would take at least some argument to show that 
every bit of An utterance: creates its own individual presumption of relevance, rather than contributing to satisfying the presumption of relevance carried by the whole utterance" (p.60). We propose that this ordering is pragmatically interpreted in terms of relevance: the higher ordered entailments are assumed to be the most relevant, to contain the point of the utterance." (S\&W, (1995). S\&W (1995) seem to be proposing that elements below the utterance level can actas a signpost or guide, highlighting the relevant aspects of an utterance: in the form of ordered entailments. In a sense S\&W (1995) do discuss linguistic features in terms of their contribution to ostension.

The relevance theoretic approach to implicature was developed by S\&W (1995) as part of a broader attempt to shift pragmatics into a cognitive framework. The relevance theorists define implicature: “... propositions which are not developments of the logical form, but rather are constructed according to a combination of contextual information and the proposition expressed by the utterance. They are totally context-dependent and not straight forwardly deducible from the utterance..." (p. 494). They have thus done much to show that a variety of different pragmatic processes are involved in developing what is encoded by An utterance: into the propositions that are actually communicated. An implicature, on the other hand, is defined as "any other propositional form communicated by an utterance; its content consists of wholly pragmatically inferred matter" (Carston, 2000: 10). They do note, however, that the conceptual content of implicatures must be wholly inferred (Carston, 2000, 2001; S\&W 2002), and to be inferred they must be intended by a speaker, and be understood by a hearer as intended (S\&W 2002).

\section{The Research Questions}

This study addresses the following research questions:

1) What roles does culture play upon the 'identity' of a writer as an evidence in his/ her linguistic choices in his/ her literary discourse?

2) What are the strategies used by an Arab writer employing his linguistic repertoire to highlight interdiscursivity of his utterances in a literary discourse?

3) What roles do the categories of the linguistic features; such as lexical items, syntactic structures and speech acts play in highlighting interdiscursivity in a literary discourse?

\section{The Research Hypotheses}

This study is based on the following research hypotheses:

1) Culture plays an effective role upon the 'identity' of a writer as an evidence in his/ her linguistic choices in his/ her literary discourse.

2) A variety of strategies are used by an Arab writer employing his linguistic repertoire to highlight interdiscursivity in a literary discourse.

3) The categories of the linguistic features; such as lexical items, syntactic structures and speech acts play an essential role in highlighting interdiscursivity in a literary discourse.

\section{Methodology}

\subsection{Data Collection}

The data of this study is selected texts taken from the novel of Abdurrahman AL-Muneif, an Arab novelist, Muden AL-melh.It is a political fiction in which Munif takes the readers to the 
heart of desert in order to make them know more about the Arab culture. Thevalley, Wadi al-Uyoun, in which the main events have taken place, is destroyed by bulldozers and heavy machinery as American engineers transform the oasis into an oil field. Munif entertains the readers and at the same time tells them a great deal about how painful the oil era has been to Arab societies. oil money has produced two cities side by side, one for the American expatriates and their elite Arab counterparts, the other for the poor, displaced Arab laborers. Munif writes convincingly about the two cultures that clash there. He captures the confusion and, in the end, the sadness wrought by the sudden change. The Bedouin laborers, earning more money than they ever dreamed possible, are told to sell their camels, which they do reluctantly. The last link to the freedom they knew as desert wanderers is gone. "Cities of Salt," is a timely and intelligent novel. It is an epic contemporary Arabic novel. It reminds the readers how rich the Arab world is in literature and how little of it they know.

\subsection{Data Analysis}

The data of the study is analyzed, as shown in Table1, according to S\&W's Relevance Theory (RT) for the sake of studying the linguistic phenomenon, interdiscursivity.

Table 1. Data analysis

\begin{tabular}{|c|c|c|c|c|}
\hline No. & Ostensive Stimulus & Ostensive contributors & Ostensive Behaviour & $\begin{array}{l}\text { Pragmatic meaning/ } \\
\text { Implicature }\end{array}$ \\
\hline 1 & 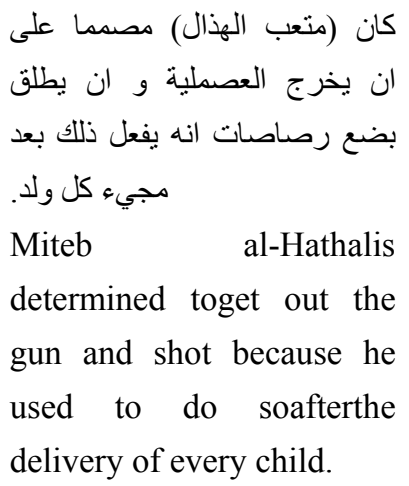 & 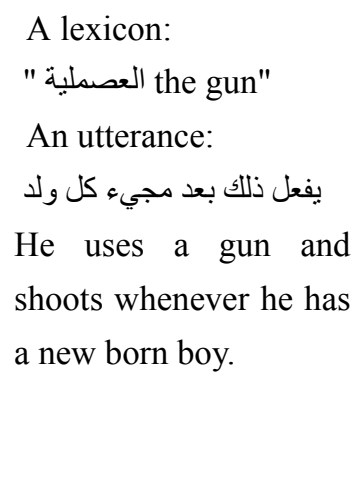 & $\begin{array}{l}\text { interdiscursivity : } \\
\text { Reference to culture } \\
\text { Use of a standard } \\
\text { variety }\end{array}$ & $\begin{array}{l}\text { The novelist intends to } \\
\text { draw the attention of } \\
\text { the reader to one of the } \\
\text { common habits of } \\
\text { Arabs which is using a } \\
\text { gun and shooting } \\
\text { whenever they have a } \\
\text { new born boy. }\end{array}$ \\
\hline 2 & 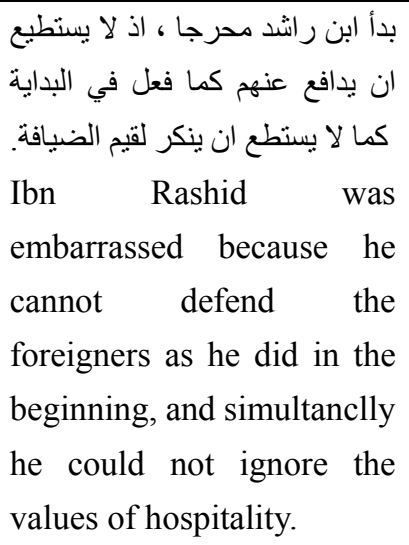 & $\begin{array}{l}\text { A phrase: } \\
\text { قيم الضيافة } \\
\text { the values of hospitality. }\end{array}$ & $\begin{array}{l}\text { interdiscursivity: } \\
\text { Reference to culture } \\
\text { Use of a standard } \\
\text { variety }\end{array}$ & $\begin{array}{l}\text { Drawing the attention } \\
\text { of the reader to the } \\
\text { hospitality of the } \\
\text { Bedouins which is one } \\
\text { of their common } \\
\text { customs. }\end{array}$ \\
\hline 3 & 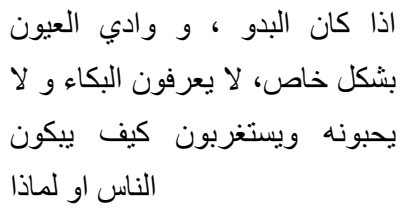 & $\begin{array}{l}\text { An utterance: } \\
\text { ويستغربون يكون البكاء و لا يحبونه ييكون الناس } \\
\text { ويكاذ لماذا }\end{array}$ & $\begin{array}{l}\text { interdiscursivity: } \\
\text { Reference to culture } \\
\text { Use of a standard } \\
\text { variety }\end{array}$ & $\begin{array}{l}\text { Spotting light on the } \\
\text { identity of the } \\
\text { Bedouins that they are } \\
\text { emotionless and very }\end{array}$ \\
\hline
\end{tabular}




\section{Macrothink 1 Institute}

\begin{tabular}{|c|c|c|c|c|}
\hline & $\begin{array}{l}\text { If the Bedouins, and the } \\
\text { people of theValley, Wadi } \\
\text { al-Uyoun, in particular, do } \\
\text { not know and do not like } \\
\text { crying and they wonder } \\
\text { how people cry or why. }\end{array}$ & $\begin{array}{l}\text { the people of theValley, } \\
\text { Wadi al-Uyoun, in } \\
\text { particular, do not know } \\
\text { and do not like crying } \\
\text { and they wonder how } \\
\text { people cry or why. }\end{array}$ & & $\begin{array}{l}\text { harsh affected by their } \\
\text { own environment. }\end{array}$ \\
\hline 4 & 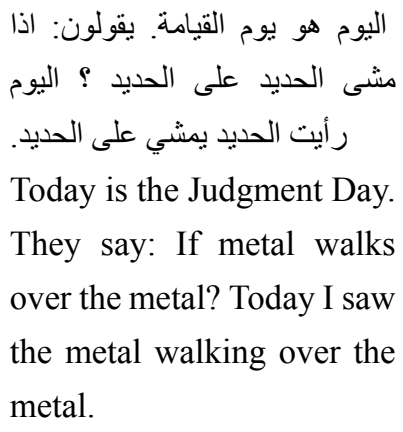 & $\begin{array}{l}\text { An utterance: } \\
\text { اليوم هو يوم القيامة. يقولون: الحديد على الحديد. } \\
\text { Today is the Judgment } \\
\text { Day. They say: If metal } \\
\text { walks over the metal? }\end{array}$ & $\begin{array}{l}\text { - interdiscursivity : } \\
\text { Reference to culture } \\
\text { - Use of a standard } \\
\text { variety }\end{array}$ & $\begin{array}{l}\text { Referring to the } \\
\text { identity of the } \\
\text { Bedouins that they } \\
\text { believe in the existence } \\
\text { of the day of judgment } \\
\text { and its indications. }\end{array}$ \\
\hline 5 & 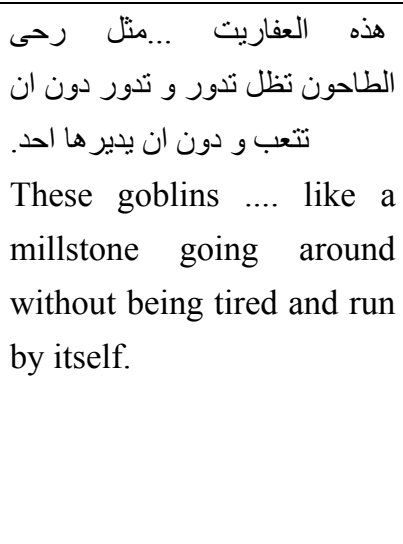 & 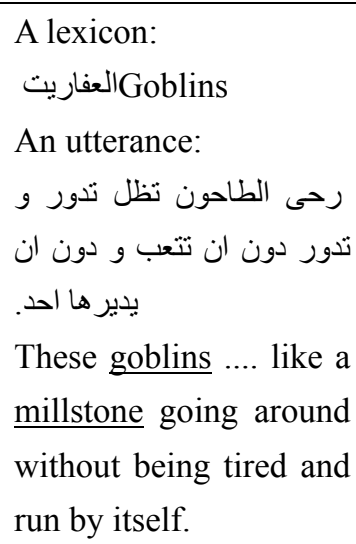 & $\begin{array}{l}\text { - interdiscursivity : } \\
\text { Reference to culture } \\
\text { Use of a standard } \\
\text { variety }\end{array}$ & $\begin{array}{l}\text { Referring to the } \\
\text { identity of the } \\
\text { Bedouins that they } \\
\text { believe in goblins and } \\
\text { to one of the common } \\
\text { devices used by them } \\
\text { which is millstone. }\end{array}$ \\
\hline 6 & 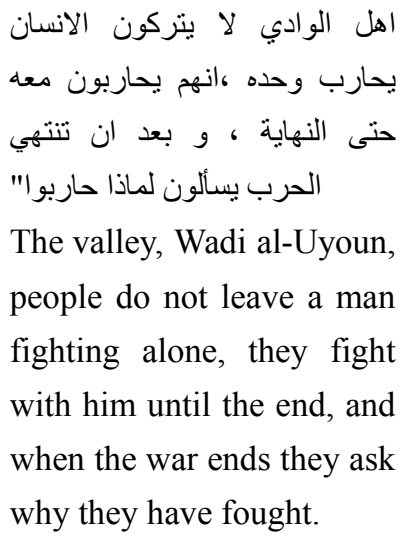 & 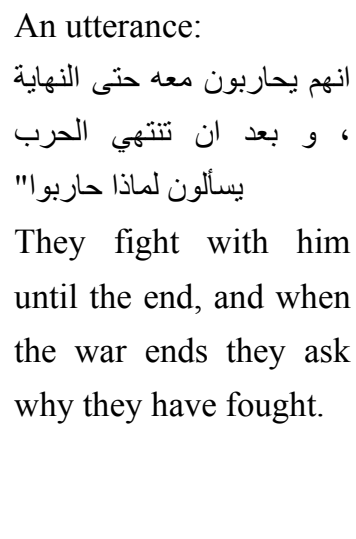 & $\begin{array}{l}\text { - interdiscursivity: } \\
\text { Reference to culture } \\
\text { - Use of a standard } \\
\text { variety }\end{array}$ & $\begin{array}{l}\text { Attracting the attention } \\
\text { to the identity of the } \\
\text { Bedouins that they are } \\
\text { very cooperative, they } \\
\text { tend to help people } \\
\text { whether they know } \\
\text { them or not. }\end{array}$ \\
\hline 7 & $\begin{array}{l}\text { كانت من عادة الامير الخروج الى في مثل هذا الوقت من السنة. } \\
\text { It was the habit of the } \\
\text { Prince that he goes to the } \\
\text { desert at this time of the } \\
\text { year. }\end{array}$ & $\begin{array}{l}\text { An utterance: } \\
\text { عادة الامير الخروج القنص } \\
\text { It was the habit of the } \\
\text { Prince that he goes to } \\
\text { the desert at this time of } \\
\text { the year. }\end{array}$ & $\begin{array}{l}\text { interdiscursivity: } \\
\text { Reference to culture } \\
\text { Use of a standard } \\
\text { variety }\end{array}$ & $\begin{array}{l}\text { Drawing the attention } \\
\text { to the Bedouins's } \\
\text { custom. }\end{array}$ \\
\hline 8 & "بسيوفنا اخذنا هذي الارض شبرا & An utterance: & - interdiscursivity : & Attracting the attention \\
\hline
\end{tabular}




\section{Macrothink 11 Institute"}

\begin{tabular}{|c|c|c|c|c|}
\hline & $\begin{array}{l}\text { وراء شبر." our swords we } \\
\text { "by our ban by } \\
\text { occupied this land span by." } \\
\text { span }\end{array}$ & 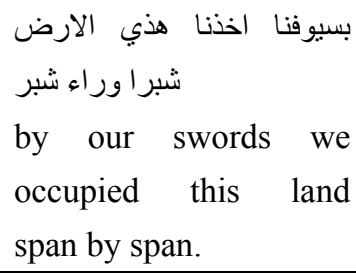 & $\begin{array}{l}\text { Reference to culture } \\
\text { Use of a dialect } \\
\text { variety }\end{array}$ & $\begin{array}{l}\text { to the identity of the } \\
\text { Bedouins that they are } \\
\text { very brave. }\end{array}$ \\
\hline 9 & $\begin{array}{l}\text { أي واحد يخلق مشاكل ما له عندنا الادواءو واحد: هذا السيف } \\
\text { For anyone, who is } \\
\text { troublesome, we have only } \\
\text { one medicine: this sword. }\end{array}$ & $\begin{array}{l}\text { An utterance: } \\
\text { ما له عندنا الا دواء واحد: هذا } \\
\text { For anyone, who makes } \\
\text { problems, we have only } \\
\text { one medicine: this } \\
\text { sword. }\end{array}$ & $\begin{array}{l}\text { interdiscursivity : } \\
\text { Reference to culture } \\
\text { Use of a dialect } \\
\text { variety }\end{array}$ & $\begin{array}{l}\text { Drawing the attention } \\
\text { to the Bedouins's } \\
\text { culture. }\end{array}$ \\
\hline 10 & $\begin{array}{l}\text { ان اكوب يشرب " بول ابليس" أب يشرب الخمر. } \\
\text { Akwab drinks"the urine of } \\
\text { the devil," which means } \\
\text { that hedrinks alcohol. }\end{array}$ & $\begin{array}{l}\text { An utterance: } \\
\text { ان اكوب يشرب " بول ابليس" انه يشرب الخمر. } \\
\text { Akwabdrinks"the urine } \\
\text { of the devil," which } \\
\text { means that hedrinks } \\
\text { alcohol. }\end{array}$ & $\begin{array}{l}\text { interdiscursivity : } \\
\text { Reference to culture } \\
\text { Use of a dialect } \\
\text { variety }\end{array}$ & $\begin{array}{l}\text { Attracting the attention } \\
\text { to Bedouins's culture. }\end{array}$ \\
\hline 11 & $\begin{array}{l}\text { وادي العيون قريب, رمية عصى. } \\
\text { The valley, Wadi al-Uyoun, } \\
\text { is as close as the distance } \\
\text { of the casting of a stick. }\end{array}$ & $\begin{array}{l}\text { A phrase: } \\
\text { رمية عصى } 10 . \\
\text { casting of a stick. }\end{array}$ & $\begin{array}{l}\text { - interdiscursivity : } \\
\text { Reference to culture/ } \\
\text { cliche } \\
\text { Use of a dialect } \\
\text { variety }\end{array}$ & $\begin{array}{l}\text { Directing the attention } \\
\text { to the Bedouins's } \\
\text { culture. }\end{array}$ \\
\hline 12 & $\begin{array}{l}\text { اعطت المريضة اعشاب المرة . } \\
\text { حضرتها بنفسها. } \\
\text { She just gave the patient } \\
\text { commiphora molmol, } \\
\text { which she has prepared } \\
\text { herself. }\end{array}$ & $\begin{array}{l}\text { An utterance: } \\
\text { اعثاب المرة، .... commiphora } \\
\text { حضرتهاب } \\
\text { The che has } \\
\text { molmolwhich she } \\
\text { prepared herself. }\end{array}$ & $\begin{array}{l}\text { interdiscursivity : } \\
\text { Reference to culture } \\
\text { Use of a standard } \\
\text { variety }\end{array}$ & $\begin{array}{l}\text { Drawing the attention } \\
\text { to the Bedouins's } \\
\text { culture. }\end{array}$ \\
\hline 13 & $\begin{array}{l}\text { نعيم لماذا صوته منخفض هكذا و يشبه صوت النساء ؟ } \\
\text { why is Naeim's voice is as } \\
\text { low as women's ?" }\end{array}$ & $\begin{array}{l}\text { An utterance: } \\
\text { نعيم لماذا صوته منخفض هكذا و يشبه صوت النساء " } \\
\text { Daham why is Naeim's } \\
\text { voice as low is as } \\
\text { women's? }\end{array}$ & $\begin{array}{l}\text { interdiscursivity : } \\
\text { Reference to culture } \\
\text { Use of a standard } \\
\text { variety }\end{array}$ & $\begin{array}{l}\text { Spotting light on the } \\
\text { Bedouins's culture. }\end{array}$ \\
\hline 14 & $\begin{array}{l}\text { في السنة عيدين و اليوم هو الثالث. } \\
\text { there are two festivals in a } \\
\text { year and today is the third. }\end{array}$ & $\begin{array}{l}\text { An utterance: } \\
\text { في السنة عيدين. } \\
\text { There are two festivals } \\
\text { in a year. }\end{array}$ & $\begin{array}{l}\text { interdiscursivity : } \\
\text { Reference to culture } \\
\text { Use of a dialect } \\
\text { variety }\end{array}$ & $\begin{array}{l}\text { Drawing the attention } \\
\text { to the culture of } \\
\text { Muslims. }\end{array}$ \\
\hline 15 & 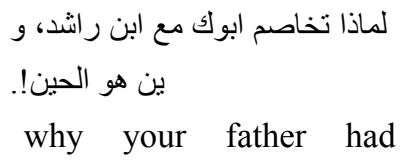 & $\begin{array}{l}\text { An utterance: } \\
\text { لماذا تخاصم ابوك مع ابن راشد، و ين الحين!. }\end{array}$ & $\begin{array}{l}\text { - interdiscursivity: } \\
\text { Reference to culture } \\
\text { - Use of a standard }\end{array}$ & $\begin{array}{l}\text { Attracting the attention } \\
\text { to the Bedouins's } \\
\text { culture. }\end{array}$ \\
\hline
\end{tabular}




\section{Macrothink}

\begin{tabular}{|c|c|c|c|c|}
\hline & $\begin{array}{l}\text { quarreled with Iben } \\
\text { arachnid, and where he is } \\
\text { now. }\end{array}$ & $\begin{array}{l}\text { why your father had } \\
\text { quarreled with } \\
\text { Ibnarachnid, and where } \\
\text { he is now. }\end{array}$ & $\begin{array}{l}\text { variety embedded by } \\
\text { a dialect variety. }\end{array}$ & \\
\hline 16 & $\begin{array}{l}\text { المبارك ما بقى له الا الكي. و اذا الكي ما افاده يكون مدبوس. } \\
\text { What has remained for } \\
\text { Almubarik is only ironing. } \\
\text { If ironing does not benefit, } \\
\text { he must be under the effect } \\
\text { of magic. }\end{array}$ & $\begin{array}{l}\text { An utterance: } \\
\text { اذا الكي ما افاده يكون مدبوس. } \\
\text { If ironing does not } \\
\text { benefit, he must be } \\
\text { under the effect of } \\
\text { magic. }\end{array}$ & $\begin{array}{l}\text { interdiscursivity : } \\
\text { Reference to culture } \\
\text { Use of a dialect } \\
\text { variety }\end{array}$ & $\begin{array}{l}\text { Directing the attention } \\
\text { of the reader to the } \\
\text { Bedouins's culture. }\end{array}$ \\
\hline 17 & $\begin{array}{l}\text { قال ما قاله، بصوت مناد, اقوى من صوت المؤن. } \\
\text { He said what he said with a } \\
\text { caller voice, stronger than } \\
\text { the voice of the prayer } \\
\text { caller. }\end{array}$ & $\begin{array}{l}\text { A phrase: } \\
\text { صوت المؤذن } \\
\text { The voice of the prayer } \\
\text { caller. }\end{array}$ & $\begin{array}{l}\text { interdiscursivity : } \\
\text { Reference to culture } \\
\text { Use of a standard } \\
\text { variety }\end{array}$ & $\begin{array}{l}\text { Attracting the attention } \\
\text { to Bedouins's culture. }\end{array}$ \\
\hline 18 & 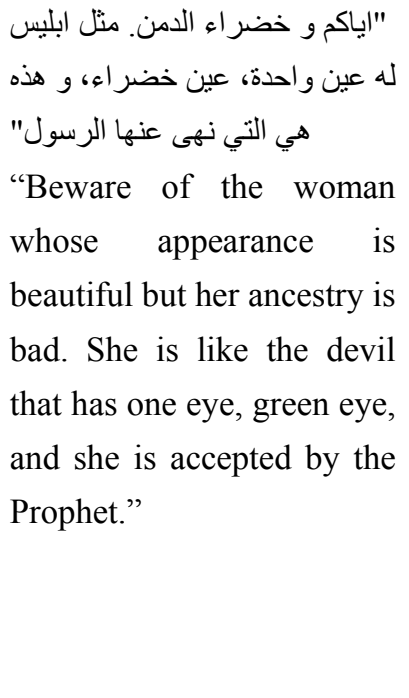 & 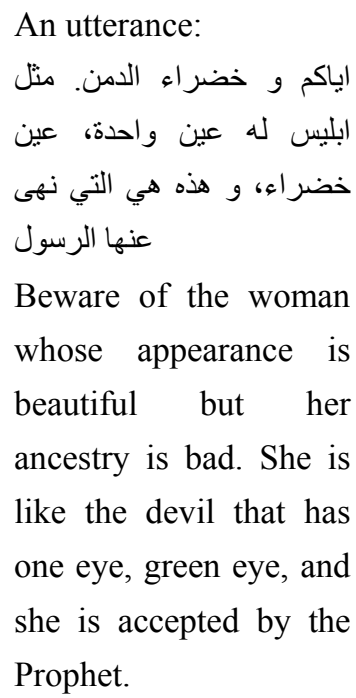 & $\begin{array}{l}\text { interdiscursivity : } \\
\text { Reference to culture } \\
\text { Use of a standard } \\
\text { variety }\end{array}$ & $\begin{array}{l}\text { Drawing the attention } \\
\text { to Bedouins's culture } \\
\text { that they know about } \\
\text { the prophet's sayings. }\end{array}$ \\
\hline 19 & $\begin{array}{l}\text { خبل.. لكن قلبه طيب. heartis } \\
\text { Dementia..buthis } \\
\text { kind. }\end{array}$ & $\begin{array}{l}\text { An utterance: } \\
\text { خبل.. لكن قلبه طيب. } \\
\text { Dementia..buthis } \\
\text { heartis kind. }\end{array}$ & $\begin{array}{l}\text { - interdiscursivity : } \\
\text { Reference to culture } \\
\text { - Use of sarcasm. } \\
\text { Use of a dialect } \\
\text { variety }\end{array}$ & $\begin{array}{l}\text { The novelist intends to } \\
\text { make the reader get to } \\
\text { know the Bedouins's } \\
\text { culture. }\end{array}$ \\
\hline 20 & 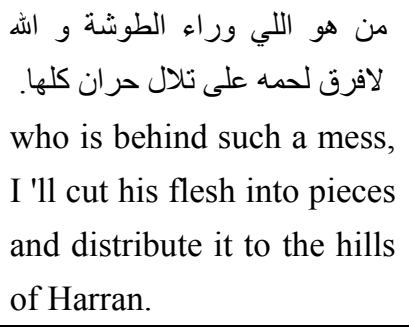 & $\begin{array}{l}\text { An utterance: } \\
\text { لا فرق لحمه على تلال حران } \\
\text { كلها. 'll cut his flesh into } \\
\text { pieces and distribute it } \\
\text { to the hills of Harran. }\end{array}$ & $\begin{array}{l}\text { interdiscursivity: } \\
\text { Reference to culture/ } \\
\text { threat } \\
\text { Use of a dialect } \\
\text { variety }\end{array}$ & $\begin{array}{l}\text { Making the reader get } \\
\text { to know the Bedouins's } \\
\text { culture. }\end{array}$ \\
\hline 21 & 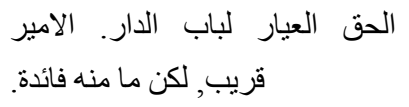 & $\begin{array}{l}\text { An utterance: } \\
\text { الحق العيار لباب الدار }\end{array}$ & $\begin{array}{l}\text { - interdiscursivity : } \\
\text { Reference to culture/ }\end{array}$ & $\begin{array}{l}\text { Drawing the attention } \\
\text { to the identity of the }\end{array}$ \\
\hline
\end{tabular}




\section{NIMacrothink}

\begin{tabular}{|c|c|c|c|c|}
\hline & $\begin{array}{l}\text { 'Follow the humorous man } \\
\text { to the door of the house'. } \\
\text { The prince is close to us, } \\
\text { but he is not beneficial. }\end{array}$ & $\begin{array}{l}\text { 'Follow the humorous } \\
\text { man to the door of the } \\
\text { house'. }\end{array}$ & $\begin{array}{l}\text { a proverb } \\
\text { Use of a dialect } \\
\text { variety }\end{array}$ & $\begin{array}{l}\text { Bedouins that they tend } \\
\text { to use proverbs in their } \\
\text { communication. }\end{array}$ \\
\hline 22 & $\begin{array}{l}\text { اذا بغيت صاحبك يدوم فحاسبه كل } \\
\text { If you want your friend to } \\
\text { continue working with you, } \\
\text { pay him daily. }\end{array}$ & $\begin{array}{l}\text { An utterance: } \\
\text { اذا بغيت صاحبك يدوم فحاسبه كل يوم. } \\
\text { If you want your friend } \\
\text { to continue working } \\
\text { with you, pay him } \\
\text { daily. }\end{array}$ & $\begin{array}{l}\text { interdiscursivity : } \\
\text { Reference to culture/ } \\
\text { a proverb } \\
\text { Use of a dialect } \\
\text { variety }\end{array}$ & $\begin{array}{l}\text { Attracting the attention } \\
\text { to the Bedouins's } \\
\text { culture. }\end{array}$ \\
\hline 23 & $\begin{array}{l}\text { من اكل تمر هم يقوم بأمر هم. } \\
\text { The one, who eats their } \\
\text { dates, should obey their } \\
\text { orders. }\end{array}$ & $\begin{array}{l}\text { An utterance: } \\
\text { من اكل تمر هم يقوم بأمر هم. } \\
\text { The one, who eats their } \\
\text { dates, should obey their } \\
\text { orders. }\end{array}$ & $\begin{array}{l}\text { interdiscursivity: } \\
\text { Reference to } \\
\text { culture/a proverb } \\
\text { Use of a dialect } \\
\text { variety }\end{array}$ & $\begin{array}{l}\text { Drawing the attention } \\
\text { to the Bedouins's } \\
\text { culture. }\end{array}$ \\
\hline 24 & $\begin{array}{l}\text { ان بغيت الفراق فاطلب بما لاق. } \\
\text { if you want to depart, you } \\
\text { ask for what is unbearable. }\end{array}$ & $\begin{array}{l}\text { An utterance: } \\
\text { ان بغيت الفراق فاطلب بما لاق } \\
\text { if you want to us depart, } \\
\text { you ask for what is } \\
\text { unbearable. }\end{array}$ & $\begin{array}{l}\text { interdiscursivity: } \\
\text { Reference to } \\
\text { culture/a proverb } \\
\text { Use of a dialect } \\
\text { variety }\end{array}$ & $\begin{array}{l}\text { Attracting the attention } \\
\text { to the Bedouins's } \\
\text { culture. }\end{array}$ \\
\hline 25 & $\begin{array}{l}\text { من جامع المصلين صلى و من المغنين غنى. } \\
\text { When a man gathers with } \\
\text { worshipers, he prays, but } \\
\text { when he gathers with } \\
\text { singers, he sings." }\end{array}$ & $\begin{array}{l}\text { An utterance: } \\
\text { من جامع المصلين صلى و من جامع المغنين غنى. } \\
\text { When a man gathers } \\
\text { with worshipers, he } \\
\text { prays, but when he } \\
\text { gathers with singers, he } \\
\text { sings. }\end{array}$ & $\begin{array}{l}\text { interdiscursivity: } \\
\text { Reference to } \\
\text { culture/a proverb } \\
\text { Use of a dialect } \\
\text { variety }\end{array}$ & $\begin{array}{l}\text { Spotting light on the } \\
\text { Bedouins's culture. }\end{array}$ \\
\hline 26 & 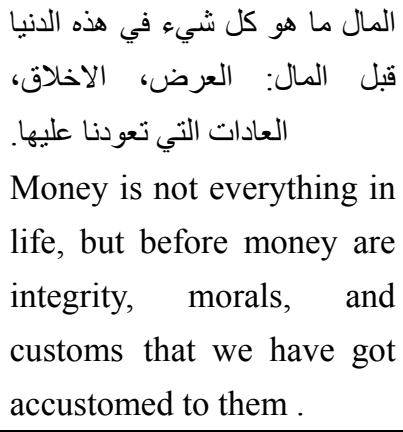 & $\begin{array}{l}\text { An utterance: } \\
\text { قبل المال: العرض، الاخلاق، } \\
\text { before money are } \\
\text { integrity, morals, and } \\
\text { customs }\end{array}$ & $\begin{array}{l}\text { interdiscursivity: } \\
\text { Reference to culture } \\
\text { / a fact } \\
\text { Use of a standard } \\
\text { variety }\end{array}$ & $\begin{array}{l}\text { Drawing the attention } \\
\text { to a fact related to the } \\
\text { identity of the } \\
\text { Bedouins. }\end{array}$ \\
\hline 27 & 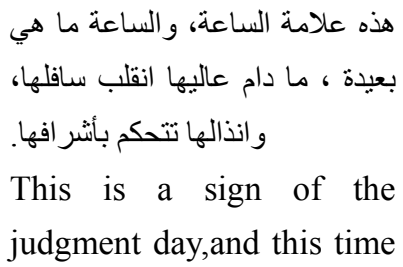 & 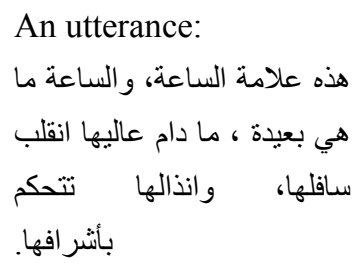 & $\begin{array}{l}\text { interdiscursivity : } \\
\text { Reference to culture/ } \\
\text { a fact } \\
\text { Use of a dialect } \\
\text { variety }\end{array}$ & $\begin{array}{l}\text { Making the reader get } \\
\text { to know the Bedouins's } \\
\text { culture. }\end{array}$ \\
\hline
\end{tabular}




\section{Macrothink Mnstitute"m}

\begin{tabular}{|c|c|c|c|c|}
\hline & $\begin{array}{l}\text { is not far, since people who } \\
\text { are in an upper place } \\
\text { turned to be in a lower } \\
\text { place, and those who are } \\
\text { viilain control the nobles. }\end{array}$ & $\begin{array}{l}\text { This is a sign of the } \\
\text { judgment day, and this } \\
\text { time is not far, since } \\
\text { people who are in an } \\
\text { upper place turned to be } \\
\text { in a lower place, and } \\
\text { those who are viilain } \\
\text { control the nobles. }\end{array}$ & & \\
\hline 28 & $\begin{array}{l}\text { هل هم رجال حقيقيون أم عفاريت؟ } \\
\text { Are they men or goblins? }\end{array}$ & 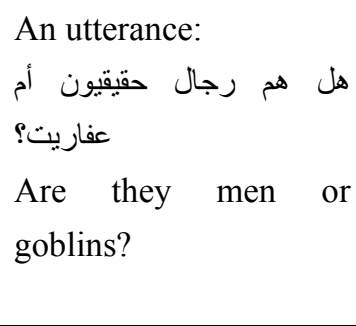 & $\begin{array}{l}\text { interdiscursivity: } \\
\text { Reference to culture } \\
\text { Use of a standard } \\
\text { variety } \\
\text { Use of a rhetorical } \\
\text { question. }\end{array}$ & $\begin{array}{l}\text { The novelist raises } \\
\text { such a type of question } \\
\text { to draw the attention of } \\
\text { the reader to the } \\
\text { Bedouins's culturethat } \\
\text { they believe in goblins. }\end{array}$ \\
\hline 29 & $\begin{array}{l}\text { كل بني ادم اخرته خرقة. } \\
\text { The end of all human } \\
\text { beings (when they die) is } \\
\text { (to be covered by) a rag. }\end{array}$ & $\begin{array}{l}\text { An utterance: } \\
\text { كل بني ادم اخرته خرقة. } \\
\text { The end of all human } \\
\text { beings is a rag. }\end{array}$ & $\begin{array}{l}\text { - interdiscursivity: } \\
\text { Reference culture/ a } \\
\text { fact } \\
\text { Use of a dialect } \\
\text { variety }\end{array}$ & $\begin{array}{l}\text { Spotting light on the } \\
\text { Bedouins's culture. }\end{array}$ \\
\hline 30 & $\begin{array}{l}\text { قال الامير :- حنا احرص منكم على الاخلاق و الدين. } \\
\text { The prince said: "We are } \\
\text { more concerned with } \\
\text { morality and religion than } \\
\text { you." }\end{array}$ & $\begin{array}{l}\text { An utterance: } \\
\text { حنا احرص منكم الاخلاق و الدين. } \\
\text { We are more concerned } \\
\text { with morality and } \\
\text { religion than you. }\end{array}$ & $\begin{array}{l}\text { - interdiscursivity: } \\
\text { Reference to religion } \\
\text { - Use of a standard } \\
\text { variety embedded by } \\
\text { a dialect variety. }\end{array}$ & $\begin{array}{l}\text { Attracting the attention } \\
\text { to the identity of the } \\
\text { Bedouins that they are } \\
\text { more concerned with } \\
\text { morality and religion. }\end{array}$ \\
\hline 31 & $\begin{array}{l}\text { عليه توكلت و اليه انيب. } \\
\text { "We trust and rely on } \\
\text { Him." }\end{array}$ & $\begin{array}{l}\text { An utterance: } \\
\text { عليه نوكلت و اليه انيب } \\
\text { We trust and rely on } \\
\text { Him. }\end{array}$ & $\begin{array}{l}\text { - interdiscursivity : } \\
\text { Reference to religion } \\
\text { Use of a standard } \\
\text { variety }\end{array}$ & $\begin{array}{l}\text { Drawing the attention } \\
\text { to the identity of the } \\
\text { Bedouins that they are } \\
\text { Muslim, they believe, } \\
\text { trust and rely on God. }\end{array}$ \\
\hline 32 & 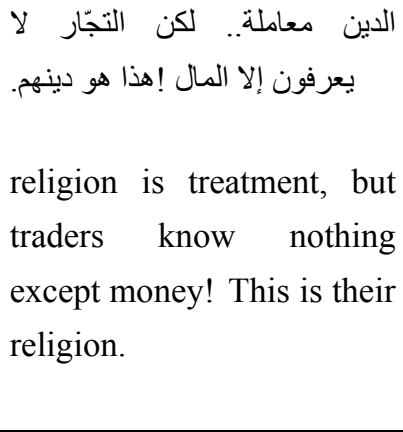 & 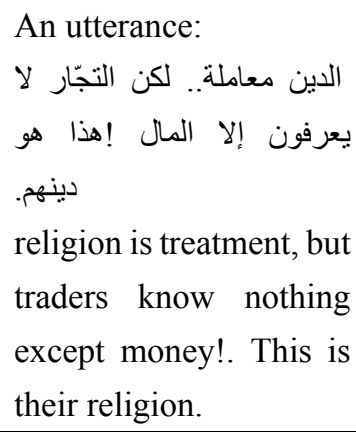 & $\begin{array}{l}\text { - interdiscursivity : } \\
\text { Reference to religion } \\
\text { Use of a standard } \\
\text { variety }\end{array}$ & $\begin{array}{l}\text { Making the reader get } \\
\text { to know the Bedouins's } \\
\text { culture. }\end{array}$ \\
\hline 33 & $\begin{array}{l}\text { التجار ... لا يعرفون الحلال ولافون من الحرام. } \\
\text { The traders ... they do not } \\
\text { know what is accepted and } \\
\text { they are not afraid of doing }\end{array}$ & $\begin{array}{l}\text { An utterance: } \\
\text { لع فئون الحلال ولا يخافون من الحرام. } \\
\text { They do not know what } \\
\text { is accepted and they are }\end{array}$ & $\begin{array}{l}\text { - interdiscursivity : } \\
\text { Reference to religion } \\
\text { Use of a standard } \\
\text { variety }\end{array}$ & $\begin{array}{l}\text { Drawing the attention } \\
\text { to the reader to the } \\
\text { identity of the } \\
\text { Bedouins. }\end{array}$ \\
\hline
\end{tabular}




\section{$1 /$ Macrothink}

Education and Linguistics Research

ISSN 2377-1356

2015, Vol. 1, No. 1

\begin{tabular}{|c|c|c|c|c|}
\hline & what is forbidden. & $\begin{array}{l}\text { not afraid of doing what } \\
\text { is forbidden. }\end{array}$ & & \\
\hline 34 & $\begin{array}{l}\text { الهمد لله رب العالمين، الرهمان } \\
\text { All praise is due to Allah, } \\
\text { the Lord of the Worlds, The } \\
\text { Beneficent, the Merciful. }\end{array}$ & $\begin{array}{l}\text { An utterance: } \\
\text { الهمد لله رب العالمين، الرهمان } \\
\text { All praise is due to } \\
\text { Allah, the Lord of the } \\
\text { Worlds, The } \\
\text { Beneficent, the } \\
\text { Merciful. }\end{array}$ & $\begin{array}{l}\text { - interdiscursivity : } \\
\text { Reference to religion } \\
\text { - Use of a broken } \\
\text { standard variety }\end{array}$ & $\begin{array}{l}\text { Attracting the attention } \\
\text { to the Bedouins's } \\
\text { culture that although } \\
\text { they are not educated } \\
\text { they know their } \\
\text { religion, Islam, well. }\end{array}$ \\
\hline 35 & $\begin{array}{l}\text { الناس مات بقلوبهم اله، الواحد منهم مثل الصل. } \\
\text { Religion does not exist in } \\
\text { people's hearts. They } \\
\text { became like a cobra. }\end{array}$ & $\begin{array}{l}\text { An utterance: } \\
\text { الناس مات بقلوبهم الله، الواحد صنار مثل الصل. } \\
\text { Religion does not exist } \\
\text { in people's hearts. They } \\
\text { became like a cobra. }\end{array}$ & $\begin{array}{l}\text { - interdiscursivity : } \\
\text { Reference to religion } \\
\text { - Use of a dialect } \\
\text { variety }\end{array}$ & $\begin{array}{l}\text { Spotting light on the } \\
\text { Bedouins's culture. }\end{array}$ \\
\hline 36 & $\begin{array}{l}\text { الله سبحانه و تعالى ، علم الانسان } \\
\text { ما لم يعلم. } \\
\text { God Almighty Makes a } \\
\text { human realize what he does } \\
\text { not know. }\end{array}$ & $\begin{array}{l}\text { An utterance: } \\
\text { الله سبحانه و تعالى ، الانسان ما لم يعلم. } \\
\text { God Almighty Makes a } \\
\text { human realize what he } \\
\text { does not know. }\end{array}$ & $\begin{array}{l}\text { - interdiscursivity: } \\
\text { Reference to religion } \\
\text { Use of a standard } \\
\text { variety }\end{array}$ & $\begin{array}{l}\text { Making the reader get } \\
\text { to know the Bedouins's } \\
\text { culture that they are } \\
\text { aware their religion, } \\
\text { Islam. }\end{array}$ \\
\hline 37 & 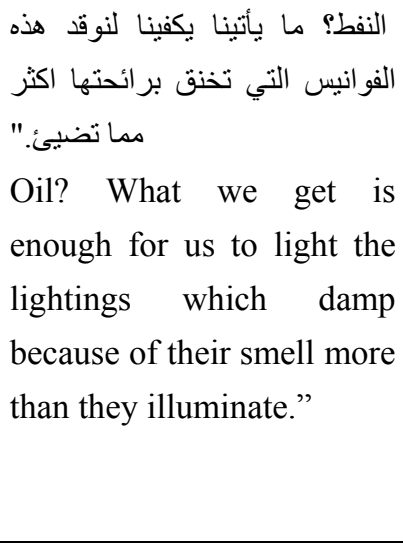 & $\begin{array}{l}\text { An utterance: } \\
\text { النفط؟ لنوقد هذه الفو انيس التي برائحنها اكثر مما } \\
\text { What we get is enough } \\
\text { for us tolight the } \\
\text { lightings which choke } \\
\text { because of their smell } \\
\text { more than they } \\
\text { illuminate. }\end{array}$ & $\begin{array}{l}\text { interdiscursivity: } \\
\text { Reference } \\
\text { environment } \\
\text { Use of a standard } \\
\text { variety embedded by } \\
\text { a dialect variety. }\end{array}$ & $\begin{array}{l}\text { Spotting light on the } \\
\text { Bedouins' environment. }\end{array}$ \\
\hline 38 & 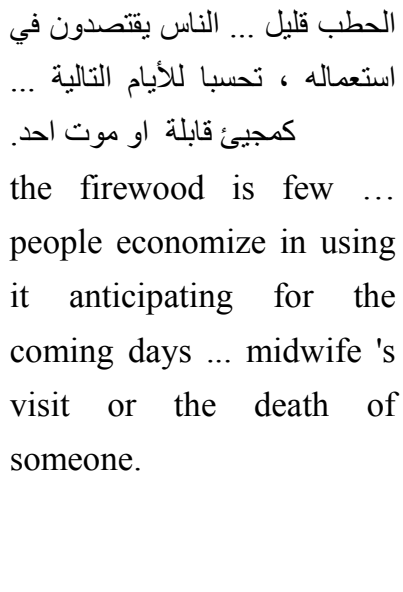 & 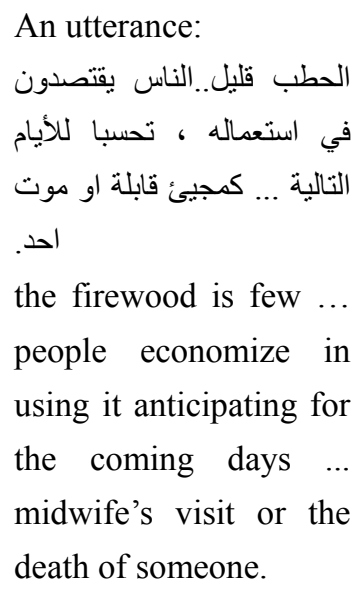 & $\begin{array}{l}\text { - interdiscursivity: } \\
\text { Reference to } \\
\text { environment } \\
\text { Use of a standard } \\
\text { variety }\end{array}$ & $\begin{array}{l}\text { Drawing the attention } \\
\text { to the Bedouins's } \\
\text { environment. }\end{array}$ \\
\hline
\end{tabular}




\begin{tabular}{|c|c|c|c|c|}
\hline 39 & $\begin{array}{l}\text { اصبح الو ادي ... اقرب ما يكون الى عو ذئاب ضالة. } \\
\text { The valley ... close to the } \\
\text { howling of lost wolves. }\end{array}$ & $\begin{array}{l}\text { A phrase: } \\
\text { عو اء ذئاب ضالة } \\
\text { howling of lost wolves. }\end{array}$ & $\begin{array}{l}\text { interdiscursivity: } \\
\text { Reference to } \\
\text { environment } \\
\text { - Use of a standard } \\
\text { variety. }\end{array}$ & $\begin{array}{l}\text { Depicting the } \\
\text { confusion in the } \\
\text { Bedouins's life after } \\
\text { the discovery of oil in } \\
\text { the desert. }\end{array}$ \\
\hline 40 & $\begin{array}{l}\text { فتح فيها اثلاما رفع النباتات الطفيلية } \\
\text { He raised the parasitic } \\
\text { و الاشواك. } \\
\text { plants and the thorns. }\end{array}$ & $\begin{array}{l}\text { A phrase: } \\
\text { النباتات الطفيلية و الاشو اك } \\
\text { "the parasitic plants and } \\
\text { thorns" }\end{array}$ & $\begin{array}{l}\text { interdiscursivity: } \\
\text { Reference to } \\
\text { environment } \\
\text { Use of a standard } \\
\text { variety }\end{array}$ & $\begin{array}{l}\text { Attracting the attention } \\
\text { to desert environment. }\end{array}$ \\
\hline 41 & $\begin{array}{l}\text { كان يتعلق بذيل الناقة و هي مسرعة كالبرق. } \\
\text { He was holding the tail of a } \\
\text { camel while it was running } \\
\text { as fast as the lightning. }\end{array}$ & $\begin{array}{l}\text { An utterance: } \\
\text { يتعلق بذيل الناقة و هي مسرعة كالبرق. } \\
\text { He was holding the tail } \\
\text { of a camel while it was } \\
\text { running as fast as the } \\
\text { lightning. }\end{array}$ & $\begin{array}{l}\text { interdiscursivity: } \\
\text { Reference to } \\
\text { environment } \\
\text { Use of a standard } \\
\text { variety }\end{array}$ & $\begin{array}{l}\text { Attracting the attention } \\
\text { to the Bedouins's } \\
\text { environment. }\end{array}$ \\
\hline 42 & $\begin{array}{l}\text { كل شيء فيهم مغلف، طبقات فوق تماما مثل الصحر اء التي } \\
\text { يعيشون فوقها. } \\
\text { Everything is covered, } \\
\text { layers one over the other } \\
\text { just like the desert in which } \\
\text { they live. }\end{array}$ & 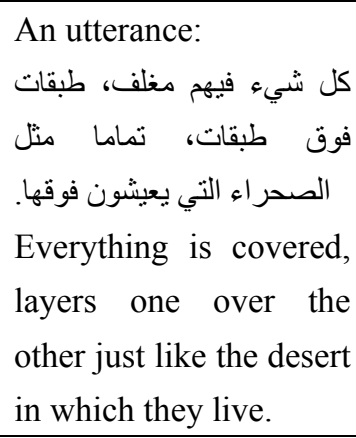 & $\begin{array}{l}\text { interdiscursivity: } \\
\text { Reference to } \\
\text { environment } \\
\text { Use of a standard } \\
\text { variety }\end{array}$ & $\begin{array}{l}\text { Giving focus on the } \\
\text { identity of the } \\
\text { Bedouins. }\end{array}$ \\
\hline 43 & $\begin{array}{l}\text { اذا دخل الشتاء و ربعت نروح للحباري. } \\
\text { When winter comes and the } \\
\text { very coldest period starts, } \\
\text { we go for hunting bustard. }\end{array}$ & $\begin{array}{l}\text { An utterance: } \\
\text { اذا دخل الشتاءوربعت نروح للحباري. } \\
\text { When winter comes and } \\
\text { the very coldest period } \\
\text { starts, we go for hunting } \\
\text { bustard. }\end{array}$ & $\begin{array}{l}\text { interdiscursivity: } \\
\text { Reference } \\
\text { environment } \\
\text { Use of a standard } \\
\text { variety embedded by } \\
\text { a dialect variety. }\end{array}$ & $\begin{array}{l}\text { Emphasizing the fact } \\
\text { that the Bedouins are } \\
\text { very much affected by } \\
\text { the desert environment. }\end{array}$ \\
\hline 44 & 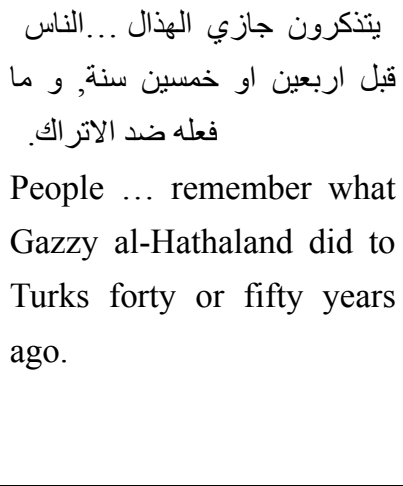 & 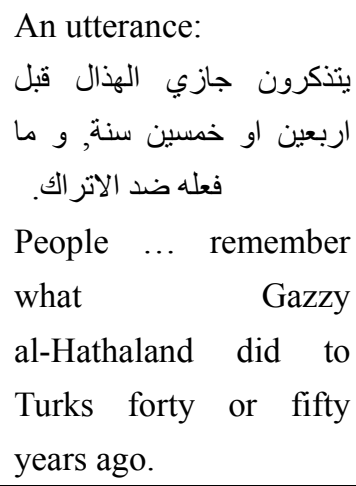 & $\begin{array}{l}\text { interdiscursivity : } \\
\text { Reference to history } \\
\text { Use of a standard } \\
\text { variety }\end{array}$ & $\begin{array}{l}\text { Attracting the attention } \\
\text { to the Bedouins's } \\
\text { history. }\end{array}$ \\
\hline 45 & كانوا اشرس اهل الو ادي في & $\begin{array}{l}\text { An utterance: } \\
\text { كانوا اثرس اهل الوادي في }\end{array}$ & $\begin{array}{l}\text { - interdiscursivity : } \\
\text { Reference to history }\end{array}$ & $\begin{array}{l}\text { Drawing the attention } \\
\text { to the Bedouins's }\end{array}$ \\
\hline
\end{tabular}




\begin{tabular}{|c|c|c|c|c|}
\hline & $\begin{array}{l}\text { They were the fiercest } \\
\text { fighters against Turks in } \\
\text { the valley. }\end{array}$ & $\begin{array}{l}\text { محاربة الاتراك. } \\
\text { They were the fiercest } \\
\text { fighters against Turks } \\
\text { in the valley. }\end{array}$ & $\begin{array}{l}\text { Use of a standard } \\
\text { variety }\end{array}$ & history. \\
\hline 46 & 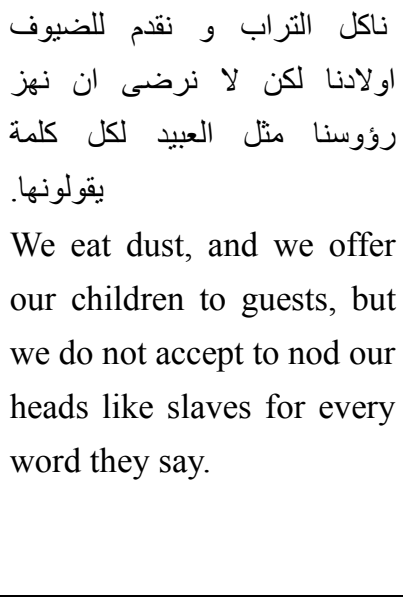 & 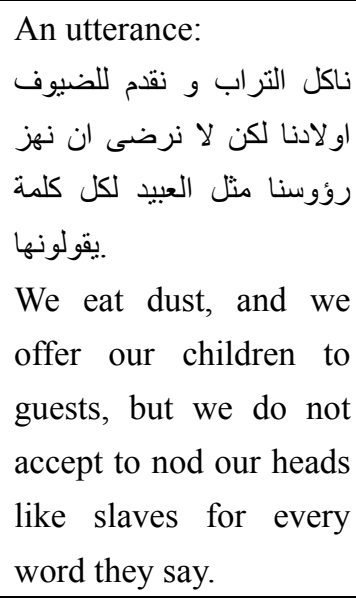 & $\begin{array}{l}\text { interdiscursivity: } \\
\text { Reference to identity } \\
\text { Use of a standard } \\
\text { variety }\end{array}$ & $\begin{array}{l}\text { Spotting light on the } \\
\text { Bedouins that they do } \\
\text { not accept to be } \\
\text { humiliated by anyone. }\end{array}$ \\
\hline 47 & 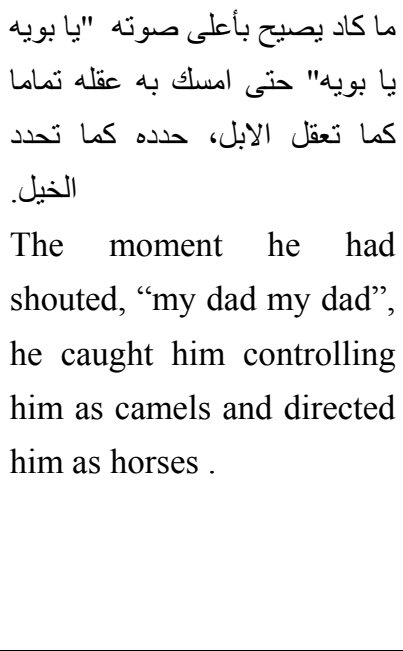 & 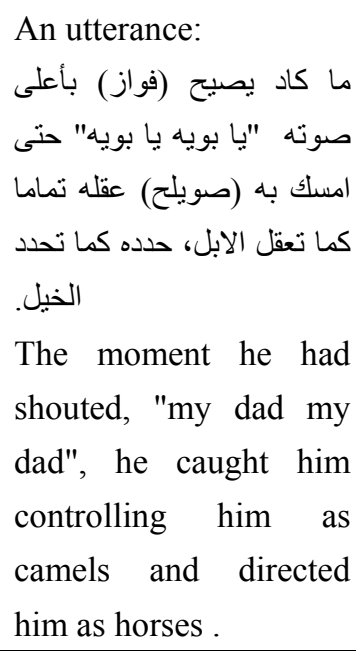 & $\begin{array}{l}\text { interdiscursivity: } \\
\text { Reference to identity } \\
\text {-Use of a standard } \\
\text { variety embedded by } \\
\text { a dialect variety. }\end{array}$ & $\begin{array}{l}\text { Directing the attention } \\
\text { to the Bedouins's } \\
\text { culture. }\end{array}$ \\
\hline 48 & 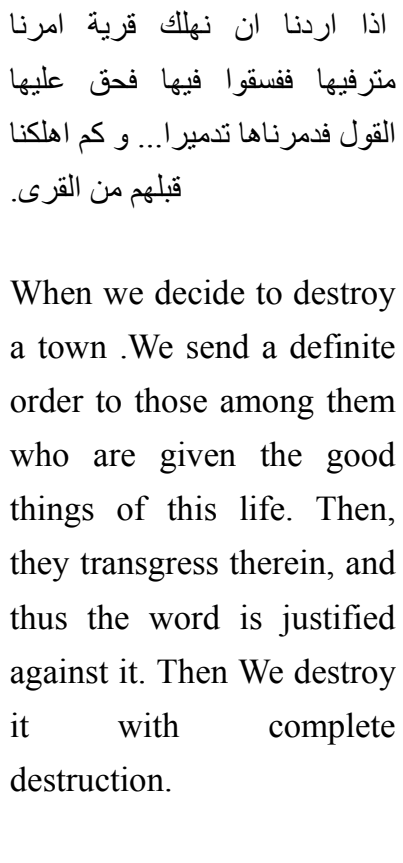 & 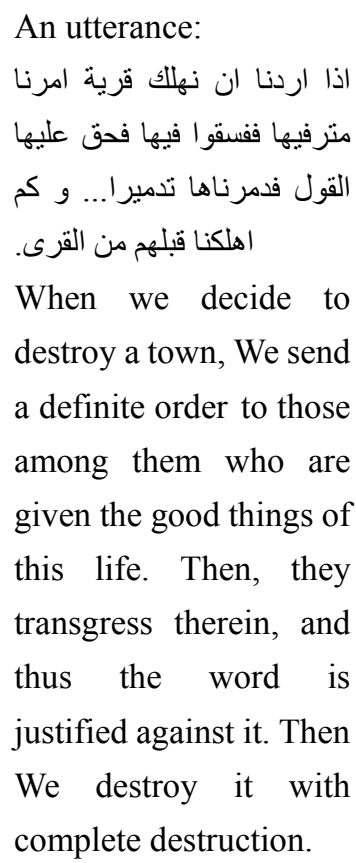 & $\begin{array}{l}\text { interdiscursivity: } \\
\text { Quotation from the } \\
\text { Holy Quran }\end{array}$ & $\begin{array}{l}\text { Drawing the attention } \\
\text { to the identity of the } \\
\text { Bedouins that they } \\
\text { consider the holy } \\
\text { Quran the guidance of } \\
\text { their life. }\end{array}$ \\
\hline
\end{tabular}




\section{Macrothink}

\begin{tabular}{|c|c|c|c|c|}
\hline 49 & $\begin{array}{l}\text { "و قل اعملوا فسيرى الله عملكم و رسوله" } \\
\text { "Tell them to work and } \\
\text { God and His Messenger } \\
\text { will see your work." }\end{array}$ & $\begin{array}{l}\text { An utterance: } \\
\text { و قل اعملوا فسيرى الله عملكم و رسوله" } \\
\text { "Tell them to work and } \\
\text { God and His Messenger } \\
\text { will see your work." }\end{array}$ & $\begin{array}{l}\text { - interdiscursivity: } \\
\text { Quotation from the } \\
\text { Holy Quran }\end{array}$ & $\begin{array}{l}\text { Directing the attention } \\
\text { to the identity of the } \\
\text { Bedouins that they } \\
\text { consider the holy } \\
\text { Quran the guidance of } \\
\text { their lives. }\end{array}$ \\
\hline 50 & $\begin{array}{l}\text { " لا تبقى و لا تذر " spares not (any sinner), } \\
\text { nor does it leave (anything } \\
\text { unburnt). }\end{array}$ & $\begin{array}{l}\text { An utterance: } \\
\text { " لا تبقى و لا تذر " } \\
\text { It spares not, nor does it } \\
\text { leave. }\end{array}$ & $\begin{array}{l}\text { - interdiscursivity: } \\
\text { Quotation from the } \\
\text { Holy Quran }\end{array}$ & $\begin{array}{l}\text { Attracting the attention } \\
\text { to the identity of the } \\
\text { Bedouins that they } \\
\text { consider the holy } \\
\text { Quran the guidance of } \\
\text { their lives. }\end{array}$ \\
\hline 51 & 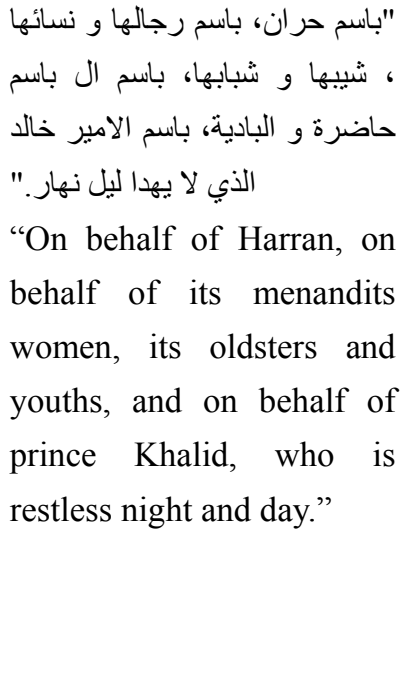 & 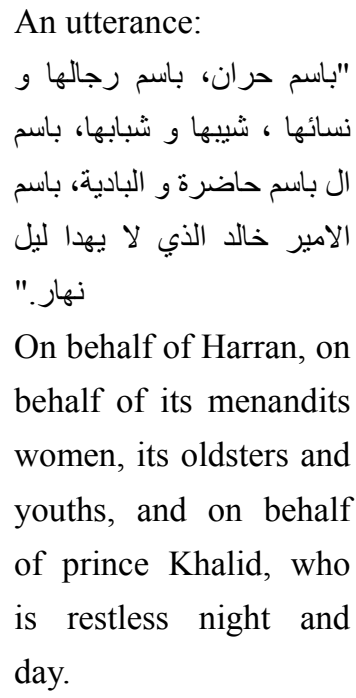 & $\begin{array}{l}\text { - interdiscursivity : } \\
\text { Use of a speech } \\
\text { Use of a dialect } \\
\text { variety. }\end{array}$ & $\begin{array}{l}\text { Spotting light on the } \\
\text { the identity of the } \\
\text { Bedouins. }\end{array}$ \\
\hline 52 & 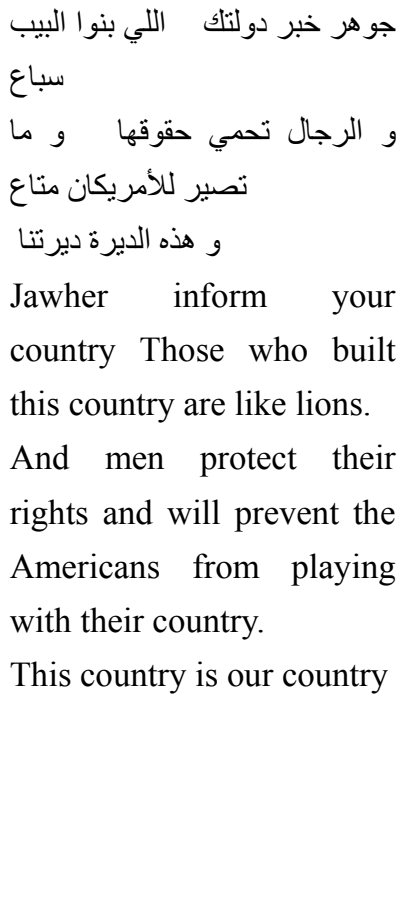 & 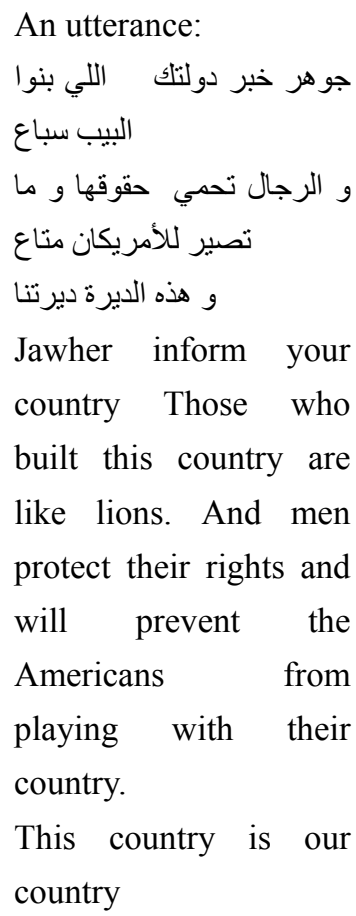 & $\begin{array}{l}\text { - interdiscursivity : } \\
\text { Use of a poem } \\
\text { Use of a dialect } \\
\text { variety }\end{array}$ & $\begin{array}{l}\text { Drawing the attention } \\
\text { to the identity of the } \\
\text { Bedouins that they like } \\
\text { to write poetry and } \\
\text { declaim it. }\end{array}$ \\
\hline
\end{tabular}




\section{Macrothink}

\begin{tabular}{|c|c|c|c|c|}
\hline 53 & 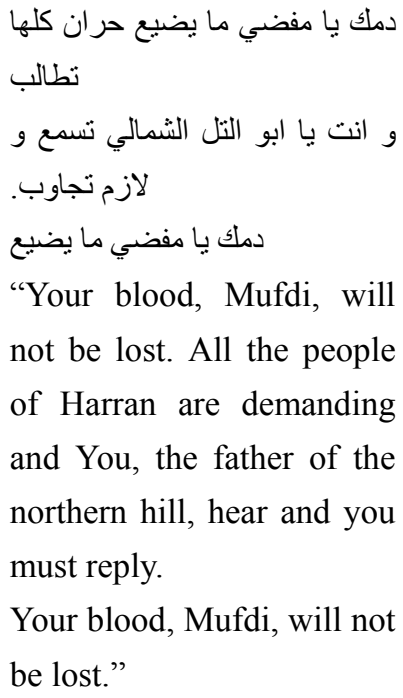 & $\begin{array}{l}\text { An utterance: } \\
\text { Your blood, Mufdi, will } \\
\text { not be lost. All the } \\
\text { people of Harran are } \\
\text { Demanding and You, } \\
\text { the father of the } \\
\text { northern hill, hear and } \\
\text { you must reply. } \\
\text { Your blood, Mufdi, will } \\
\text { not be lost. }\end{array}$ & $\begin{array}{l}\text { interdiscursivity : } \\
\text { Use of a poem } \\
\text { Use of a dialect } \\
\text { variety. }\end{array}$ & $\begin{array}{l}\text { Spotting light on the } \\
\text { identity of the } \\
\text { Bedouins that they like } \\
\text { to write poetry and } \\
\text { declaim it. }\end{array}$ \\
\hline 54 & 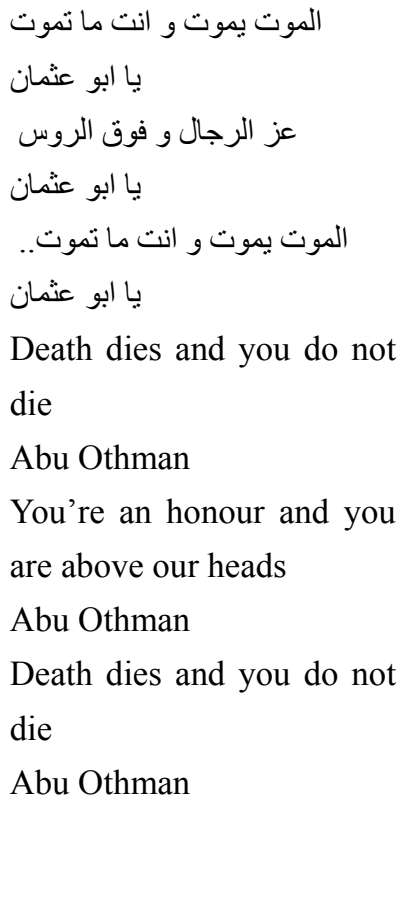 & 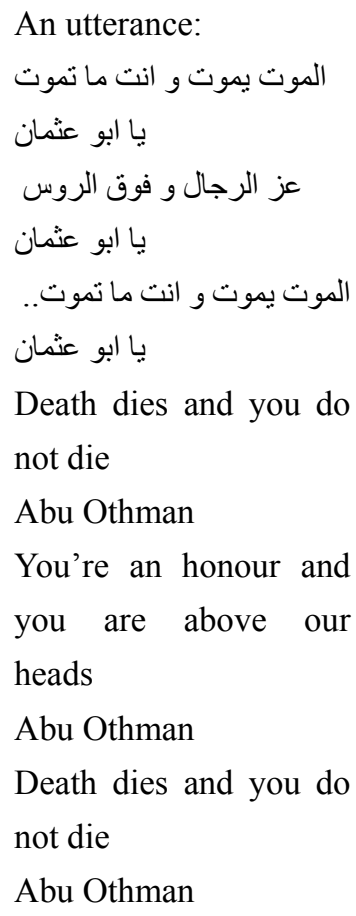 & $\begin{array}{l}\text { interdiscursivity : } \\
\text { Use of a poem } \\
\text { Use of a dialect } \\
\text { variety }\end{array}$ & $\begin{array}{l}\text { Attracingt the attention } \\
\text { to the identity of the } \\
\text { Bedouins that they like } \\
\text { to write poetry and } \\
\text { declaim it. }\end{array}$ \\
\hline 55 & 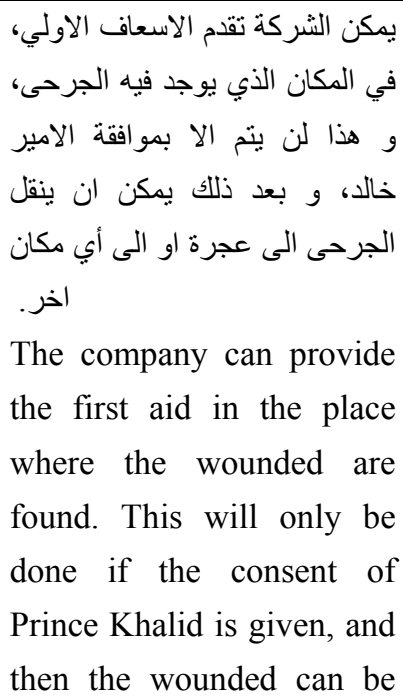 & $\begin{array}{l}\text { An utterance: } \\
\text { The company can } \\
\text { provide the first aid in } \\
\text { the place where the } \\
\text { wounded are found ... } \\
\text { if the consent of Prince } \\
\text { Khalid is given, and } \\
\text { then the wounded can } \\
\text { be transferred to the } \\
\text { Ajrah or to any other } \\
\text { place. }\end{array}$ & $\begin{array}{l}\text { interdiscursivity: } \\
\text { Use of a legal } \\
\text { discourse } \\
\text { Use of a standard } \\
\text { variety. }\end{array}$ & $\begin{array}{l}\text { Directing the attention } \\
\text { to a legal discourse. }\end{array}$ \\
\hline
\end{tabular}




\begin{tabular}{|c|c|c|c|c|}
\hline & $\begin{array}{l}\text { sent to the Ajrah or to any } \\
\text { other place. }\end{array}$ & & & \\
\hline 56 & 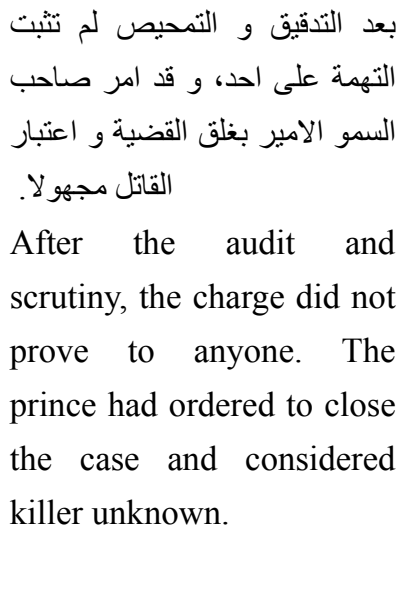 & 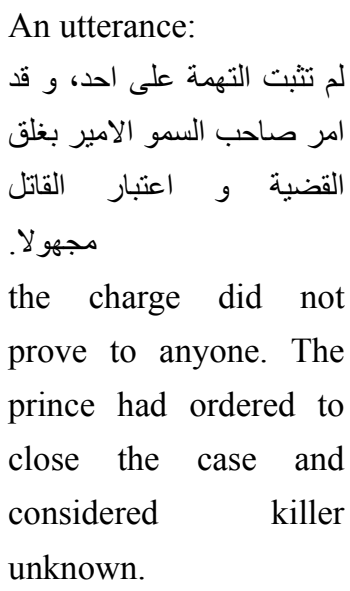 & $\begin{array}{l}\text { - interdiscursivity: } \\
\text { Use of a legal } \\
\text { discourse } \\
\text { Use of a standard } \\
\text { variety. }\end{array}$ & $\begin{array}{l}\text { Attracting the attention } \\
\text { to the use of a legal } \\
\text { discourse. }\end{array}$ \\
\hline 57 & 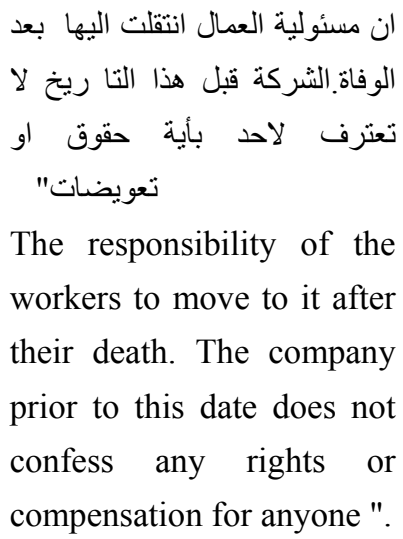 & 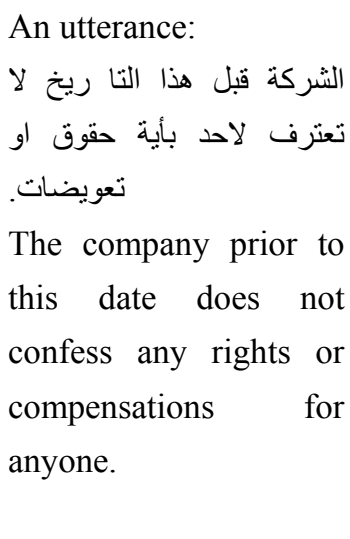 & $\begin{array}{l}\text { - interdiscursivity : } \\
\text { Use of a legal } \\
\text { discourse } \\
\text { Use of a standard } \\
\text { variety. }\end{array}$ & $\begin{array}{l}\text { Spotting light on a } \\
\text { legal discourse. }\end{array}$ \\
\hline 58 & 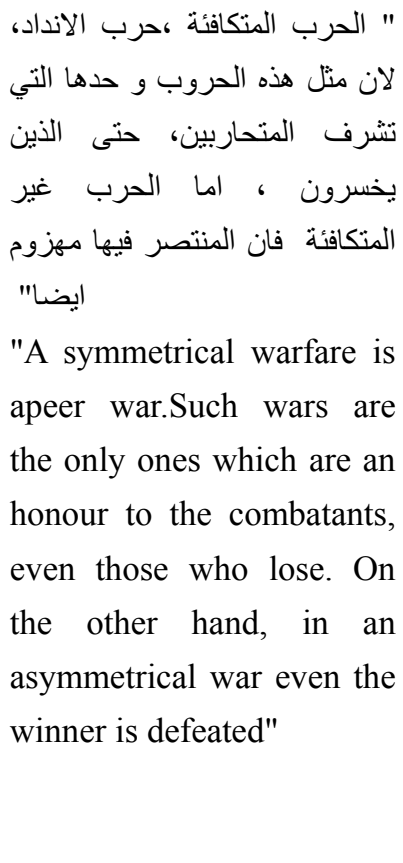 & 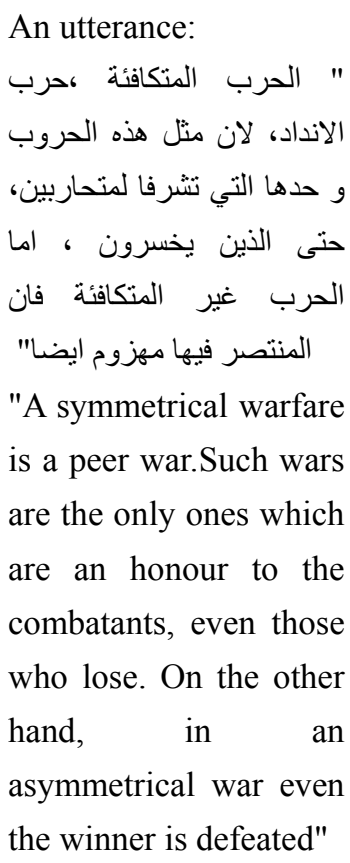 & $\begin{array}{l}\text { - interdiscursivity: } \\
\text { Use of a political } \\
\text { discourse } \\
\text { Use of a standard } \\
\text { variety. }\end{array}$ & $\begin{array}{l}\text { Spotting light on the } \\
\text { use of a political } \\
\text { discourse. }\end{array}$ \\
\hline 59 & عدر عن ديوان الامارة البلاغ القصبر التالي: & 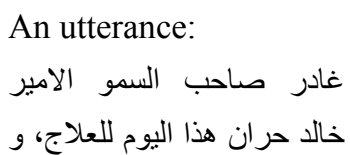 & $\begin{array}{l}\text { - interdiscursivity: } \\
\text { Use of a political } \\
\text { discourse }\end{array}$ & $\begin{array}{l}\text { Spotting light on the } \\
\text { use of a political } \\
\text { discourse. }\end{array}$ \\
\hline
\end{tabular}




\section{Mll Macrothink}

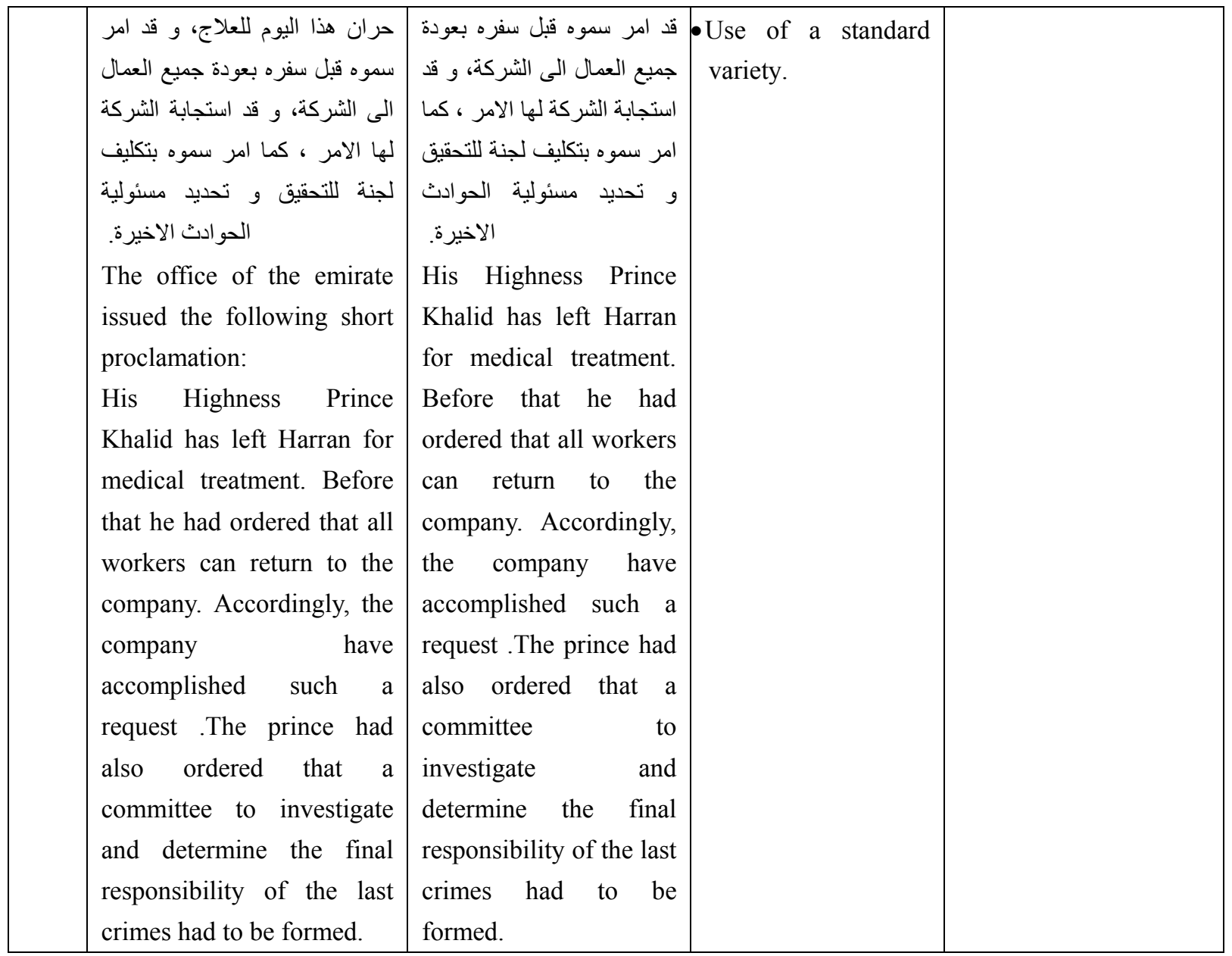

\section{Conclusion}

S\&W's notion of ostensive stimuli has the ability to provide a firmer theoretical basis for an RT form of social language analysis, with a particular reference to discourse analysis, giving a detailed description of the relevance notion of ostension as an act of intentionally highlighting or directing the addressee's attention to certain information. Ostensive behavior made this information relevant to the interactants' mutual cognitive environment in the form of explicatures or implicatures. This study has provided a means of considering some concepts in RT which may be utilized to bridge the gap between the theoretical underpinnings of this paradigm that describes interdiscursivity. The result, hopefully, provides some insights into the way in which RT may be employed with more theoretical strength to social aspects of communication. This study has attempted to apply RT by affirming the function of ostension contributors as signposts for relevance, and by re-identifying some of the units of analysis which bear this function.

\section{The Results}

a) The stylistic approach has successfully introduced the social and cultural factors into the analysis of the linguistic structures. This view helps in understanding the macro relationship between literature and social/ historical context, as shown in 43- 44 in Table 1. It is through this dynamic linguistic phenomenon, interdiscursivity, literature achieves its unique charm and aesthetic value. 
b) It is shown through the analysis of the literary ostensive stimulus of the study data that culture plays an effective role upon the 'identity' of an Arab writer as an evidence in his theme choices by using interdiscursivity; such as the reference to the common habits and the customs of Arabs, as in 1 in Table 1, the identity of the Bedouins, as in 46 and 47 in Table 1, the Bedouins's environment, as in 37-43 in Table 1, the Arab proverbs, as in 21-25 Table 1, poetry, as in 52-54 in Table 1 and the Holy Quran, as in 48-50 in Table 1.

c) A variety of ostensive behaviours are used by an Arab writer employing his linguistic repertoire to highlight the efficient role of interdiscursivity in a literary discourse; such as the use of a standard variety, as in 1 and 6 in Table 1; a dialect variety, as in 7-10 in Table 1; a standard variety embedded by a dialect variety, as in 14, 30, 37,43 and 47 in Table 1; the use of rhetorical questions, as in 26 in Table 1; sarcasms, as in 18 in Table 1; threats, as in 19 in Table 1; and the reference to culture, as in 1-29 in Table 1; environment, as in 37- 43 in Table 1, Arabian proverbs, as in 21-25 in Table 1 factual, as in 29 in Table 1; religious, as in 30-36 in Table 1; political, as in 58-59 historical, as in 44-45 in Table 1 and legal discourses, as in $55-57$ in Table 1.

d) Interdiscursivity, as a marked linguistic form or ostension contributor, supports efficiently to the contextual effect on the mutual cognitive environment of the interactants, as shown in in all the examples in Table 1.

e) S\&W's notion of ostension is usefully discussed not only in the level of an uttrance ,but below the utterance level to the linguistic structures as well, such as marked words, , as in 1 and 5 in Table 1 , and phrases as in 2, 11, 17,3 9 and 40 in Table 1. This contributes to ostension and, therefore, to the analysis of interdiscursivity depending on the context in which they are used.

f) The pieces of Ostensive Stimulus allow an analyst to determine how the relevance of an utterance is realised, and particularly for this research, why interdiscursivity is used. These aspects of the linguistic ostension contributors are described as a means of adding to the highlighting, signaling, signposting or indicating the relevance of an utterance.

g) The ostension contributors, which carry with them the presumption of relevance, for example in 16 in Table 1, where the word "ironing" according to the reader's background knowledge indicates a means of medical treatment and "magic", a tool used to destroy man's life, and the intended messages of a writer. These ostension contributors are used to add to the utterance's ostensive behavior. They make manifest the intention to make something manifest - forms which help construct the relevance of an utterance for describing the occurrence of interdiscursivity.

h) It has been proven in this study that implicatures are interpreted according to the background knowledge of a reader and his inferences about a current situation as a whole rather than from inferences about the intentions of a writer, such as his knowledge about culture, as in 1-25 in Table 1, environment, as in 37- 43 in Table 1, Arabian proverbs, as in 21-25 in Table 1 factual, as in 29 in Table 1 ; religious, as in 30-36 in Table 1; political, as in 58-59 in Table 1, historical, as in 44-45 in Table 1and legal discourses , as in 55 -57 in Table 1.

i) The arguments presented in this research demonstrate that there is nothing intrinsically 


\section{Al Macrothink}

asocial about RT. Any attempt to explain behaviour by reference to the social environment implies certain information processing abilities. RT seeks to provide an explicit account of these abilities and is, therefore, of great potential value to an adequate understanding of humans as social beings, as shown all examples presented in Table 1.

\section{References}

Allen, G. (2000). Intertextuality. London: Routledge.

Anymous. (1986). Speech genres and other late essays. Austin: University of Texas Press.

Bakhtin, M. (1981). The dialogic imagination. Austin: University of Texas Press.

Bernstein, B. (1996). Pedagogy, symbolic control and identity. London: Taylor \& Francis.

Blakemore, D. (1987). Semantic Constraints on Relevance. Oxford: Blackwell. The intuitive basis of implicature 132.

Blass, R. (1990). Relevance Relations in Discourse. Cambridge: Cambridge UP. http://dx.doi.org/10.1017/CBO9780511586293

Bradford, R. (1997). Stylistics. New York: Routledge.

Carston, R. (2000). Explicature and Semantics. UCL Working Papers in Linguistics, 12, 1-44.

Carston, R. (2001). Relevance theory and the saying/implicating distinction. UCL Working Papers in Linguistics, 13, 1-34.

Carston, R., \& Seiji, U. (1998). Relevance Theory: Applications and Implications. Amsterdam: John Benjamins. http://dx.doi.org/10.1075/pbns.37

Chouliaraki, L., \& Fairclough, N. (1999). Discourse in Late Modernity. Edinburgh University Press, Edinburgh.

Clark, B. (1991). Relevance Theory and the Semantics of Non-Declaratives. PhD Diss.U of London.

Collins, J. (1989). Uncommon cultures: Popular culture and postmodernism. New York: Routledge.

Dan, S., \& Deirdre, W. (1997). Remarks on Relevance Theory and the Social Sciences. Multilingua, 16(2-3), 145-51. http://dx.doi.org/10.1515/mult.1997.16.2-3.145

Dan, S., \& Deridre, W. (2002). Pragmatics, modularity, and mind-reading. Mind and Language, 17(1/2), 3-23.

Wilson, D., \& Sperber, D. (1986). Inference and Implicature. In S. Davis (Ed.). Pragmatics: A Reader (pp. 378-93). Oxford: Oxford UP.

Deirdre, W. (1991). Linguistic Form and Relevance. Lingua, 90(1), 1-25.

Robyn, C., \& Seiji, U. (1998). Pragmatics and time. In R. Carston, \& S. Uchida (Eds.), Relevance Theory. Applications and Implications (pp. 1-22). Amsterdam: John Benjamins. http://dx.doi.org/10.1075/pbns.37

Fairclough, N. (1992). Discourse and social change. Cambridge: Polity Press. http://dx.doi.org/10.1177/0957926592003002008

Hutcheon, L. (1989). The politics of postmodernism. London: Routledge. http://dx.doi.org/10.4324/9780203426050

Knee, A. (1994). The compound genre film: Billy the Kid versus Draculameets The Harvey 
Girls. In E. Cancalon \& A. Spacagna (Eds.). Intertextuality in literature and film. (pp. 141-156). Gainesville, F.L.: University Press of Florida.

Kristeva, J. (1986). Word, dialogue and novel. In T. Moi (Ed.), The Kristeva reader (pp. 34-61). Oxford: Blackwell,

Jary, M. (1998). Is Relevance Theory Asocial? Revista Alicantina de Estudios Ingleses, 11, 157-69.

Lemke, J. L. (1995). Textual politics: Discourse and social dynamics. London: Taylor \& Francis.

Levinson, S. (1989). A review of Relevance. Journal of Linguistics, 25(2), 455-472. http://dx.doi.org/10.1017/S0022226700014183

Norman, F. (2003). Analyzing discourse: Text analysis for social research. London: Routledge.

Norman, F. (2010). Critical discourse analysis: The critical study of language (2nd ed.). London: Longman.

Pilkington, A. (1991). Poetic Effects: A Relevance Theory Perspective. Literary Pragmatics. In R. Sell. (Ed.), London: Routledge.

Roberts, L. (1991). Relevance as an Explanation of Communication. Linguistics and Philosophy, 14, 453-72. http://dx.doi.org/10.1007/BF00630924

Ruiz de M., F. (1999). The role of cognitive mechanisms in making inferences. Journal of English Studies: University of La Rioja, 1, 237-255.

Ruiz de M., F., \& Hernandez, L. (2001). Cognitive operations and pragmatic implication, Sincronia. E-Journal of Culture Studies. Retrieved from http://sincronia.cusch.udg.mx/fall01.htm.

Nicolle, S., \& Clark, B. (1999). Experimental pragmatics and what is said: A response to Gibbs and Moise. Cognition, 69(3), 337-354.

Scollon, R. (2000). Methodological interdiscursivity: An ethnographic understanding of unfinalisability. In S. Sarangi \& M. Coulthard (Eds.), Discourse and social life (pp. 138-154). London: Pearson Education Limited.

Sperber, D. (1987). Precis of Relevance: Communication and Cognition. Behavioral and Brain Sciences, 10(4), 697-754. http://dx.doi.org/10.1017/S0140525X00055345

Sperber, D., \& Wilson, D. (1995). Relevance: Communication and Cognition. (2nd Ed.), Oxford: Blackwell.

Sperber, D., \& Wilson, D. (1982). On defining relevance. In R. Grundy \& R. Warner (Eds.), Philosophical Grounds of Rationality (pp. 243-258). London: Academic Press.

Sperber, D., \& Wilson, D. (1986). Relevance: Communication \& Cognition. Oxford: Blackwell.

Sperber, D., \& Wilson, D. (1995). Relevance: Communication \& Cognition (2nd edition). Oxford: Blackwell.

Wilson, D. (1998). Discourse, Coherence and Relevance: A Reply to Rachel Giora. Journal of Pragmatics, 29(1), 57-74. http://dx.doi.org/10.1016/S0378-2166(97)00012-X 


\section{Macrothink}

Education and Linguistics Research

ISSN 2377-1356 2015, Vol. 1, No. 1

Wodak, R. (2001). The discourse-historical approach. In R. Wodak \& M. Meyer (Eds.), Methods of critical discourse analysis [ABRIDGED]. (pp. 63-95). London: Sage. http://dx.doi.org/10.4135/9780857028020.n4

Xin, B. (2000). Intertextuality from a Critical Perspective. Suzhou: Suzhou University Press.

Yus Ramos, F. (1998). A Decade of Relevance Theory. Journal of Pragmatics, 30(3), 305-45. http://dx.doi.org/10.1016/S0378-2166(98)00015-0

Zir, Y. (1989). On the Rationality of 'Relevance' and the Relevance of Rationality. In Ada Kasher (Ed.). Cognitive Aspects of Language Use. Amsterdam: Elsevier Science.

\section{Copyright Disclaimer}

Copyright reserved by the author(s).

This article is an open-access article distributed under the terms and conditions of the Creative Commons Attribution license (http://creativecommons.org/licenses/by/3.0/). 